IZA DP No. 9220

Decomposing the Wage Losses of Displaced Workers: The Role of the Reallocation of Workers into Firms and Job Titles

Pedro S. Raposo

Pedro Portugal

Anabela Carneiro

July 2015 


\title{
Decomposing the Wage Losses of Displaced Workers: The Role of the Reallocation of Workers into Firms and Job Titles
}

\author{
Pedro S. Raposo \\ Universidade Católica Portuguesa, Lisboa \\ Pedro Portugal \\ Banco de Portugal, Universidade Nova de Lisboa and IZA \\ Anabela Carneiro \\ CEF.UP, Universidade do Porto \\ Discussion Paper No. 9220 \\ July 2015 \\ IZA \\ P.O. Box 7240 \\ 53072 Bonn \\ Germany \\ Phone: +49-228-3894-0 \\ Fax: +49-228-3894-180 \\ E-mail: iza@iza.org
}

\begin{abstract}
Any opinions expressed here are those of the author(s) and not those of IZA. Research published in this series may include views on policy, but the institute itself takes no institutional policy positions. The IZA research network is committed to the IZA Guiding Principles of Research Integrity.

The Institute for the Study of Labor (IZA) in Bonn is a local and virtual international research center and a place of communication between science, politics and business. IZA is an independent nonprofit organization supported by Deutsche Post Foundation. The center is associated with the University of Bonn and offers a stimulating research environment through its international network, workshops and conferences, data service, project support, research visits and doctoral program. IZA engages in (i) original and internationally competitive research in all fields of labor economics, (ii) development of policy concepts, and (iii) dissemination of research results and concepts to the interested public.
\end{abstract}

IZA Discussion Papers often represent preliminary work and are circulated to encourage discussion. Citation of such a paper should account for its provisional character. A revised version may be available directly from the author. 


\section{ABSTRACT \\ Decomposing the Wage Losses of Displaced Workers: The Role of the Reallocation of Workers into Firms and Job Titles*}

Using an unusually rich matched employer-employee-job title data set for Portugal, this paper evaluates the sources of wage losses of workers displaced due to firm closure based on the comparison of workers' wages differentials before and after displacement. Potential wage losses of displaced workers can be related to firm, job title, and match heterogeneity in the pre- and post-displacement jobs. In this vein, we estimate a three-way high-dimensional fixed effects regression model that enables us to decompose the sources of the wage losses into the contribution of firm, job title, and match fixed effects. The worker-firm match plays a very sizable role. We found that the allocation of workers into poorer matches accounts for 38 percent of the total average wage loss. Sorting among firms accounts for 36 percent. Job downgrading also plays a significant role in explaining the wage loss of displaced workers, accounting for the remaining 26 percent.

JEL Classification: J31, J63, J65, E24

Keywords: $\quad$ wage losses, displaced, high-dimensional fixed effects, job title, match effects

Corresponding author:

Pedro S. Raposo

Católica Lisbon School of Business and Economics

Universidade Católica Portuguesa

Palma de Cima

1649-023 Lisbon

Portugal

E-mail: pedro.raposo@ucp.pt

\footnotetext{
* The authors are grateful for helpful comments and suggestions from António Antunes, Paulo Guimarães, Daniel S. Hamermesh, Joop Hartog, Tobias Klein, Matteo Picchio, Jan van Ours, Arthur van Soest, and José Varejão. We also thank participants at the SOLE2013, EALE2013, EEA2013, $9^{\text {th }}$ IZA/World Bank, and $20^{\text {th }}$ IPDC conferences. The usual disclaimer applies. Pedro S. Raposo gratefully acknowledges financial support from the Portuguese Foundation of Science and Technology, FCT [SFRH/BD/21906/2005]. Part of this work was carried out while he was visiting the Bank of Portugal, whose support is gratefully acknowledged. We are grateful to the Portuguese Ministry of Employment for access to the data and thank Lucena Vieira for outstanding data and computational assistance. CEF.UP - Centre for Economics and Finance at the University of Porto is funded by Fundação para a Ciência e Tecnologia; project reference: PEst-OE/EGE/U14105/2014.
} 


\section{Introduction}

Worker displacement is the subject of an extensive and growing literature. The costs of job loss in terms of unemployment, future employment prospects, and earnings-change have been the most studied aspects of job displacement. ${ }^{1}$ Focusing on the last of these, this paper provides a detailed decomposition of the evolution of the earnings gap between displaced and non-displaced workers into its most important dimensions - firm, job title, and match characteristics. Understanding the causes of these reductions might shed some light on potential policy options to ease the burden of adjustment on these workers, and should offer additional empirical evidence regarding the "new monopsony" approach of the labor market popularized by Manning (2003).

Earlier literature on the earnings impact of job displacement has now convincingly established that displaced workers experience long-lasting reductions in earnings (Couch and Placzek (2010) and Davis and von Wachter (2011)). However, the mechanisms generating these losses is a matter of some controversy. This study offers a novel evaluation of the sources of wage losses incurred by workers displaced due to firm closure, having in mind that wages in the previous job are a function of a set of worker characteristics (e.g., gender, education, and experience) that are expected to yield, in general, the same return on the previous job and in the labor market and a set of firm, job title, and match characteristics that do not necessarily yield the same return in subsequent jobs (Hamermesh (1987)). Indeed, if wages primarily reflect workers' characteristics, then individual wages will be highly persistent, largely invariant to where individuals work, and potential losses due to displacement will be negligible. If, on the other hand, firm, job title, and match-specific heterogeneity are important, then the costs of displacement supported by workers could be considerable.

It is well documented in the empirical literature on wage differentials drawn from linked employer-employee data that observed and unobserved characteristics of workers, firms, and worker-firm matches are important determinants of wages (Abowd et al. (1999), Goux and Maurin (1999), Woodcock (2008), and Torres et al. (2013)). Furthermore, firms seem to be quite heterogenous in terms of their market power and wage compensation policies (Cardoso (2000) and Webber (2013)). The existence of labor market frictions such as imperfect information and mobility costs can explain the persistence of interfirm/inter-industry compensation differentials (e.g., Burdett and Mortensen (1998)). These search frictions give firms monopsony power and the possibility to offer a wage that deviates from the competitive market wage (Manning, 2003, 2011). Even in more centralized wage setting systems like the one prevailing in Portugal, firms often deviate from the wage floor agreed at the collective bar-

\footnotetext{
${ }^{1}$ For enlightening reviews of the literature see Hamermesh (1989), Kletzer (1998) and Carrington and Fallick (2014).
} 
gaining table for each category of workers, adjusting to firm-specific conditions (Cardoso and Portugal (2005)).

The role of assortative matching is also likely to be relevant in the setting up of our analysis. In this framework, it is important to distinguish a good worker in a good firm from a good worker-firm match. In the event of a displacement, a loss occurs if a high quality job match between the worker and the firm is dissolved..$^{2,3}$ Furthermore, match-specific human capital accumulated over the course of the employment relationship is permanently destroyed when a job separation occurs. Its value is lost for both - match participants and to the society as a whole (Woodcock (2007)).

Moreover, accounting for match quality has important consequences in terms of the econometric model specification. It is not sufficient to account solely for worker and firm unobserved effects, as the omission of match effects biases the estimated returns to observed characteristics and the estimated worker and firm fixed effects. ${ }^{4}$ In the current study we separate the role of the quality of the match from the role of worker and firm permanent heterogeneity.

To account for occupational heterogeneity in the pre- and post-displacement jobs, this study considers a third dimension of wage formation - job title heterogeneity. A major strength of our dataset is that it matches the workers with their corresponding job titles. The identification of job titles is thorough and reliable because it comes directly from the definition of wage floors settled by collective bargaining. In a typical year around 30,000 wage floors are agreed (Martins (2014) and Carneiro et al. (2014)). The detailed definition of the job titles accounts for the complexity of the tasks, the hierarchical standing of the worker, and the stressfulness of the working conditions. A displacement event could lead to the loss of occupation-specific human capital due to the difficulty of finding a job that uses existing skills optimally or due to the depreciation of general and specific human capital during non-employment spells. ${ }^{5}$ It is worth noting that human capital has a decisive role during the early phase of the joblessness spell. It can be argued that larger human capital endowments are associated with greater job opportunities and higher opportunity costs of unemployment that necessarily erode with the progression of the unemployment spell.

Earlier literature has sought to evaluate this effect by measuring specific human capital based on tenure at the occupation, firm, and industry level.

\footnotetext{
${ }^{2}$ However, displacement might increase earnings. For instance, if displacement dissolves a bad job match that was not perceived as such by the employee.

${ }^{3}$ See, among others, the studies of Abraham and Farber $(1987,1988)$, Altonji and Shakotko (1987), Topel (1991), and Dustmann and Meghir (2005).

${ }^{4}$ For a detailed discussion on the consequences of omitting match effects see Woodcock (2007).

${ }^{5}$ See Poletaev and Swaim (2008) and Kambourov and Manovskii (2009) for enlightening discussions on the role of occupational specific human capital as a major determinant of earnings.
} 
However, a long job tenure may signal the high unobserved quality of the match and/or a high ability worker, because more able workers and workers in good jobs are less likely to separate. To account for endogeneity bias due to correlation of tenure with the unobserved effects, earlier studies used an IV approach (see, among others, Neal (1995), Parent (2000), Poletaev and Swaim (2008), and Kambourov and Manovskii (2009)).We contribute to the literature by addressing this source of wage loss looking directly at changes of job titles before and after displacement and by using a fixed effects approach that allows for arbitrary correlation among the regressors and the unobserved effects.

To sensibly incorporate these many wage determinants, our methodology relies heavily on the estimation of a wage equation with three high-dimensional fixed effects - worker, firm, and job title - using a nationally representative matched employer-employee-job title data set - Quadros de Pessoal (QP) that allows us, based on the omitted variables bias formula (Gelbach (2016)), to compute the independent contribution of each unobserved fixed effect to the monthly wage losses of displaced workers. The universal coverage of the employed population in the private sector in Portugal combined with these econometric tools creates the favorable conditions for this exercise.

In sum, the contribution of this paper to the current literature is threefold. First, we are confident that by incorporating match and job title fixed effects we are able to provide refined estimates (filtered from worker, firm, job title, and match heterogeneity) of the corresponding sources of earnings losses. Second, based on the methodology developed by Gelbach (2016), which appeals to the omitted variables bias formula, we are able to unambiguously disentangle the sources of the wage losses into the contribution of firm, job title, and match fixed effects. Third, relying on a different definition of job title, we are able to provide further empirical evidence regarding its relative importance as a source of wage losses. Actually, using a definition of job title that takes into account the architecture of the Portuguese bargaining system, which shares the same essential features of most countries in continental Europe (see, for example, Burda and Mertens (2001) for Germany and Garda (2012) for Spain), we are confident of the strength of the external validity of our exercise.

Even though Portugal and the U.S. have different institutional labor market frameworks (Blanchard and Portugal (2001)), our results are in accordance with earlier studies for the U.S. Based on the JLS methodology, the wages loss estimates reported here represent, eight years after the separation event, a penalty of 12 percent on pre-displacement wages.

Furthermore, we conclude that the worker-firm match plays a non-negligble role as a source of the wage losses of the displaced.The unfavorable allocation into firms and job titles that are less generously remunerated also plays an important role. Overall, allocation of workers into poorer matches accounts for 38 percent of the average wage loss, while job downgrading accounts for 26 percent. The remaining 36 percent is accounted for by the firm fixed effects. 
The remainder of the paper is structured as follows. Section 2 describes the data and the sample construction. Section 3 presents a brief description of the Portuguese wage bargaining system and discusses the notion of job title. The empirical methodology and the results are presented in Section 4. Section 5 concludes.

\section{The data}

\subsection{Quadros de Pessoal data set}

In this study we use a longitudinal matched employer-employee data set called Quadros de Pessoal (QP - "Lists of Personnel") for the 1986-2013 period. The data are gathered annually by the Portuguese Ministry of Employment through an inquiry that every establishment with even a single wage-earner is obliged by law to fill in. Reported data cover the firm, the establishment, and each of its workers. Currently, QP gathers information on more than 300,000 firms and about 3 million workers. Given the mandatory nature of the survey plus the fact that these data cover all wage earners in the private sector in Portugal, problems commonly associated with panel data sets, such as panel attrition, are considerably reduced.

Data reported on the worker side include gender, age, schooling, and detailed information on monthly earnings - base wages, regular payments (e.g., seniority), irregular benefits (profit distributions and premiums), overtime payments, and hours of work (normal and overtime). The information on earnings is reported by the employer, which is known to be subject to less measurement error than worker-provided earnings data. ${ }^{6}$

As mentioned above, this survey is conducted on a yearly basis, and its identifying scheme allows for accurate identification of firms and workers, making it possible to track them over the years. Each firm entering the database is assigned a unique identifying number and the Ministry implements several checks to ensure that a firm that has already reported to the QP dataset is not assigned a different identification number. Using this identifier it is possible to pinpoint all firms that have entered and exited economic activity. In particular, an exit from the database should signal a firm that has ceased its activity. The firm data include detailed information on industry, region, ownership type, and size. The worker's identification number is based on the social security number. Finally, this source enables the matching of firms and their workers, which allows us to control for match characteristics.

\footnotetext{
${ }^{6}$ All earnings variables were deflated using the Consumer Price Index (with base-year 2008).
} 


\subsection{Sample construction - displaced workers}

Our "treatment" group includes 22 cohorts of workers who lost their jobs between 1988 and 2011 due to firm closure. ${ }^{7}$ Firm closures were identified based on the firm's identifying number. Thus, a firm is classified as an exiting firm in year $t+1$ if it is present in the QP files in year $t$, but absent in $t+1, t+2$ and all of the subsequent years. To ensure that we are in the presence of firms' true closures and not mergers or acquisitions, we excluded from the sample those workers that appeared in the database in the period following displacement with a year of admission in the new job less than the year of displacement minus one. ${ }^{8}$ These exclusions reduced the sample size by around $1.6 \%$.

Within the reference period, some individuals experience successive spells of firm closure in firms that are necessarily different. For identification purposes, and to be more precise, we used information from only the first firm closure within the reference period. Thus, only the first firm closure is used to identify a displacement and the years before and after are used relative to that year of displacement.

For comparison purposes the samples used in this study are selected as in JLS and Couch and Placzek (2010). To be included in the sample a worker must report positive earnings in the year that immediately precedes the displacement event and must be continuously employed with the same employer during the first three years (screening period). This means that workers are selected into the sample with at least three years of tenure by the time of the reference year. Furthermore, a worker must report positive earnings at least once thereafter, and have known information on his/her age. The sample was restricted to full-time wage earners in the private non-farm sector aged between 16 and 64 years during the final year of the screening period and that were employed in a firm with at least 20 employees (these restrictions reduced the sample size by 38 percent).

For estimation purposes we define a measure of time relative to the displacement event (reference year is $\mathrm{D}_{0}$ ). For example, we define $\mathrm{D}_{0}$ in 1997 for the 1997 displaced group, $\mathrm{D}_{0}$ in 1998 for the 1998 displaced group, and so on. The data set combines 22 cohorts (1988-2011) of displaced workers over the 1986-2013 period ranging from $\mathrm{D}_{-10}$ up to $\mathrm{D}_{10} \cdot{ }^{9}$

In sum, the sample includes all displaced individuals who are employed in the year that immediately precedes the displacement, $D_{0}$, and at least two periods before the reference year $\left(D_{-2}\right)$ and who are present in the QP registers

\footnotetext{
${ }^{7}$ For example, the 1997 "treatment" group comprises individuals who were working in 1997 and experienced a displacement event between years 1997 and 1998 (the firm closed down between November 1997 and September 1998).

${ }^{8}$ If, for example, a worker's displacement year is 1997 and (s)he appears in the database in the post-displacement period with a year of admission in the new job of 1996 or earlier, (s)he is excluded from the sample.

${ }^{9}$ It should be noted that worker files are not available for the years 1990 and 2001.
} 
Table 1: Sample composition: displaced workers

\begin{tabular}{lr} 
Year & Displaced \\
\hline$D_{-10}$ & 16285 \\
$D_{-9}$ & 22593 \\
$D_{-8}$ & 26780 \\
$D_{-7}$ & 35962 \\
$D_{-6}$ & 44730 \\
$D_{-5}$ & 52791 \\
$D_{-4}$ & 62436 \\
$D_{-3}$ & 77034 \\
$D_{-2}$ & 92780 \\
$D_{-1}$ & 95527 \\
$D_{0}$ & 116815 \\
$D_{1}$ & 34838 \\
$D_{2}$ & 47718 \\
$D_{3}$ & 51136 \\
$D_{4}$ & 51040 \\
$D_{5}$ & 46402 \\
$D_{6}$ & 41755 \\
$D_{7}$ & 39088 \\
$D_{8}$ & 34404 \\
$D_{9}$ & 32311 \\
$D_{10}$ & 31948 \\
Total & $1,054,373$ \\
\hline Notes: The sample includes all displaced in- \\
dividuals who are employed in the year of the \\
displacement $D_{0}$ and at least two periods be- \\
fore displacement $\left(D_{-2}\right)$ and who are in reem- \\
ployment in at least one year before the end of \\
the sample period.
\end{tabular}

in at least one year of the post-displacement period. Table 1 reports the number of worker/year observations for the sample of workers displaced due to firm closure. According to Table 1, 116,815 workers were displaced due to firm closure in the 1988-2011 period (1,054,373 worker-year observations). 
Table 2: Sample composition: non-displaced workers

\begin{tabular}{rrr} 
Year & Non-displaced & Displaced \\
\hline 1986 & 583990 & 13277 \\
1987 & 617751 & 16985 \\
1988 & 611681 & 19247 \\
1989 & 637351 & 22884 \\
1991 & 699676 & 28207 \\
1992 & 716426 & 31308 \\
1993 & 708907 & 33933 \\
1994 & 714354 & 34527 \\
1995 & 766647 & 41721 \\
1996 & 751205 & 43238 \\
1997 & 800776 & 48979 \\
1998 & 800269 & 52144 \\
1999 & 813800 & 56954 \\
2000 & 826691 & 57295 \\
2002 & 812054 & 47713 \\
2003 & 816926 & 49894 \\
2004 & 864708 & 51557 \\
2005 & 911886 & 55457 \\
2006 & 938036 & 54835 \\
2007 & 970006 & 53962 \\
2008 & 997136 & 52671 \\
2009 & 963099 & 48055 \\
2010 & 1017983 & 43562 \\
2011 & 1033436 & 33453 \\
2012 & 995861 & 31269 \\
2013 & 987023 & 31246 \\
Total & $21,357,678$ & $1,054,373$ \\
\hline & &
\end{tabular}

\subsection{Sample construction - non-displaced workers}

The group of non-displaced workers (the control group) includes all individuals who were employed in firms that did not close in the 1986-2013 period. The group of non-displaced workers was also restricted to full-time wage earners in the private non-farm sector aged between 16 and 64 years and that were employed in a firm with at least 20 employees.

In order to guarantee that the worker was employed with the same employer in the pre-displacement period, we checked the firm's identifying number assigned to the worker over that period. These workers were followed over the 
post-displacement period if they remained with the same employer over that period.

After excluding those observations with missing values in the explanatory variables and the extreme values in wages ( $0.1 \%$ top and bottom observations), we obtained a control group composed of $21,357,678$ non-displaced worker/year. Table 2 reports the number of observations per year in the sample of nondisplaced workers over the 1986-2013 period.

\subsection{Sample description}

Table 8 in Appendix A presents the descriptive statistics in the reference period for both groups of workers - displaced and non-displaced. Displaced workers are slightly younger and have fewer years of education and tenure in comparison with their non-displaced counterparts. Moreover, the proportion of women is higher in the group of displaced workers when compared with the group of non-displaced. As expected, firms that close down are smaller and are mainly operating in the sectors of manufacturing and wholesale and retail trade.

Displaced workers earn significantly lower wages than their non-displaced counterparts. The average real monthly wage amounts to 1,067 euros for the displaced, while for the non-displaced it equals 1,258 euros. Furthermore, a simple descriptive statistics comparison suggests that displaced workers experienced substantial long-term monthly earnings losses following displacement. As shown in Figure 1, the average monthly earnings of workers who separated in 1997 fell sharply in comparison with their non-displaced counterparts.

\section{Identification of job titles}

In this section we provide a brief description of the architecture of the Portuguese wage bargaining system and a detailed discussion on how job titles were identified in our approach.

\subsection{The Portuguese wage bargaining system}

The Portuguese Constitution provides the legal principles of collective bargaining and grants unions the right to negotiate. The effects of the agreements are formally recognized and considered valid sources of labor law.

Concerning the bargaining mechanisms, a distinction should be made between the conventional regime and the mandatory regime. Conventional bargaining results from direct negotiation between employers' and workers' representatives. A mandatory regime, on the other hand, does not result from direct bargaining between these two, but is instead dictated by the Ministry of Employment. The Ministry can extend an existing collective agreement to other workers initially not covered by it, or it can create a new one if it is not viable to extend the application of an existing document. A mandatory regime 
Figure 1: Monthly earnings of workers separating in year 1997 and non-displaced workers

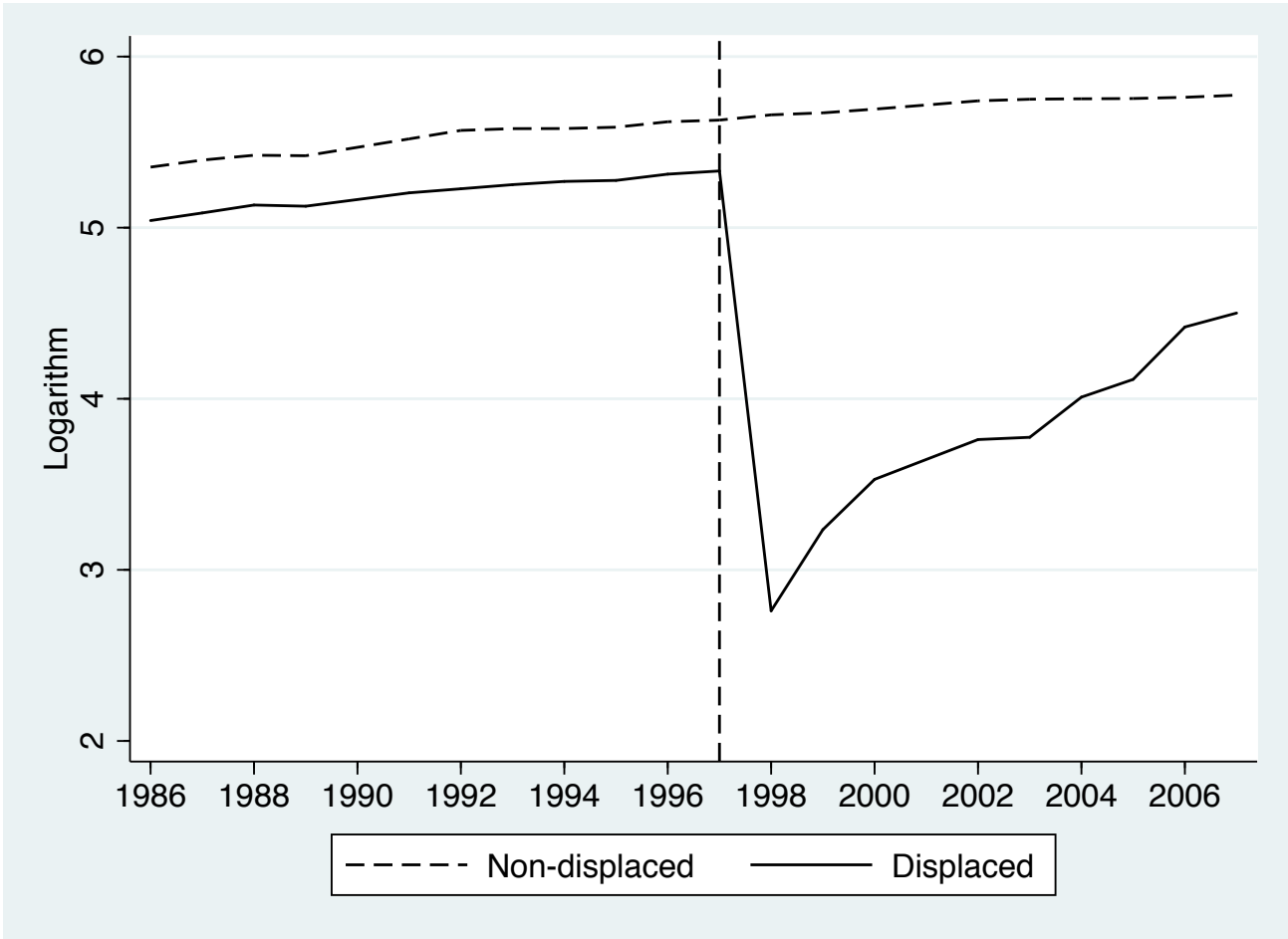

Notes: Log monthly earnings. If a worker does not appear in the dataset zero earnings are assumed.

is applied when workers are not covered by unions, when one of the parties involved refuses to negotiate, or bargaining is obstructed in any other way. Overall, coverage of collective agreements in the Portuguese private sector is above 90 percent.

Beyond the existence of compulsory extension mechanisms, voluntary extensions are also possible when one economic partner (workers' representative or employer) decides to subscribe to an agreement that it had initially not signed. Therefore, the impact of collective bargaining goes far beyond union membership and the distinction between union and non-union workers or firms becomes largely meaningless.

Collective negotiations are conducted at the industry or, occasionally, at the occupation level. Firm-level negotiation, which for a time was a common practice in large public enterprises, has lost importance. The law does not establish mechanisms of coordination between agreements reached in different negotiations; however, preference is given to vertical over horizontal agreements, and 
the principle of the most favorable condition to the worker generally applies.

Since most collective agreements are industry-wide, covering companies of very different size and economic condition, their contents tend to be general, setting minimum working conditions, in particular the base monthly wage for each category of worker, overtime pay, and the normal duration of work. ${ }^{10}$ Moreover, few topics are updated annually, and therefore the content of collective agreements is often pointed out as being out-of-date and containing little innovation.

Whatever the wage floor agreed upon for each category of worker at the collective bargaining table, firms are free to pay higher wages, and they often deviate from that benchmark, adjusting to firm-specific conditions. Cardoso and Portugal (2005) call this the "wage cushion", the difference between thecontractual part of the wage and the actual wage. They estimate that in 1999 actual wages exceeded the level of bargained wages by $20-50$ percent.

\subsection{The notion of job title}

This paper revisits the earnings losses literature by offering an overall assessment of the sources of those losses with an emphasis on the role of the job title.

In our framework the notion of job title comes simply from the identification of distinct occupational categories within each collective wage agreement. It is worth noting that the Ministry of Employment collects the QP data in order to check if employers are complying with the wage floors agreed upon for each occupational category. In QP each worker in each year is assigned to the conflation of her/his professional category (at the 5 digits level) and corresponding collective agreement. Overall, in a given year there are around 30,000 collective agreements/job title combinations to which workers can be assigned. Even though in Portugal collective negotiations are conducted at the industry or, to a lesser extent, occupation level, it is possible that similar workers employed in the same firm-occupation can earn different wages if they are covered by different collective agreements, e.g., a secretary in the banking industry agreement as opposed to a secretary in the retail trade collective agreement.

As pointed out by Martins (2014), "These agreements establish a large number of working conditions that apply to the signatory parties, including minimum wages by job type and job tenure but also many other issues such as working time, fringe benefits, training, health and safety, promotions, contract types, severance pay, bonuses, grievances, etc."

Hence, job titles summarize the general and specific skills of the worker, in particular those that are industry and occupation specific. Given the way those job titles were identified, they may also reflect the bargaining power

\footnotetext{
${ }^{10}$ See Hartog et al. (2002) for the effects of bargaining regimes.
} 
of the workers' and the employers' associations. Because job titles contain the skill requirements of the position held by the worker, they also retain the hierarchical standing of the workers. In our framework, a change in the job title could lead:

(i) to a switch in the professional category code within the same collective agreement; holding other factors constant, severe losses in the returns to the job title may represent a job downgrading due to the difficulty of finding a job that uses existing skills optimally or due to the depreciation of general or specific human capital during non-employment spells or to a loss of job shopping rents (Johnson (1978), Addison and Portugal (1987) and Topel and Ward (1992));

(ii) to a switch in the collective agreement, this change may reflect the loss/gains of rents associated with the bargaining power of unions and employers' associations at the bargaining table and industry specific skills (Neal $(1995)) ;{ }^{11}$

(iii) to a switch in the hierarchical standing within the same collective agreement/professional category; this type of change is quite often related to the loss of tenure in the previous job/firm and should reflect the loss of returns on specific human capital (Hamermesh (1987)); the nature of this change may also be related with the loss of rents associated with promotion practices inside the firm.

\section{Empirical results}

\subsection{JLS statistical specifications}

To evaluate the effect of displacement on earnings we start by using the methodological framework used by JLS. The first statistical specification assumes that workers' earnings at a given time period depend on displacement and on some controls for fixed and time-varying characteristics of the worker and the economy:

$$
w_{i t}=\alpha_{i}+\gamma_{t}+\beta X_{i t}+\sum_{k \geq-m} D_{i t}^{k} \delta_{k}+\epsilon_{i t}
$$

where $w_{i t}$ represents the monthly earnings (in logs and real euros) for each individual $i$ in year $t$. Monthly earnings correspond to total regular and non-regular payroll (base wage, regular payments, non-regular benefits, and overtime payments) in the reference month. Labor earnings are taken as zero whenever the individuals are out of work. $D_{i t}^{k}$ are dummy variables where $k$ is equal to $-m,-(m-1), \ldots, 0,1,2, \ldots$, which represent jointly the event of displacement. $\delta_{k}$ represents the effect of displacement on worker's earnings $k$ years prior to, and following, its occurrence. The worker fixed effect, $\alpha_{i}$, captures the impact

\footnotetext{
${ }^{11}$ Recall that the same professional category could be covered by a different collective bargaining mechanism, as mentioned above.
} 
of permanent differences among worker's observed and unobserved characteristics, and $\gamma_{t}$ are calendar year fixed effects included to capture the general aggregate time pattern of earnings in the economy. Finally, the vector $X_{i t}$ controls for age and age squared. $\epsilon_{i t}$ is an error term, assumed to be uncorrelated with the covariates. Our identification strategy follows closely the one explored by JLS. In a nutshell, we compare the earnings changes of displaced workers over a long-term period with the earnings changes that would have occurred if the displaced had not lost their jobs. Since this latter outcome variable is not observable, a comparison group of non-displaced workers is used. We assume that after controlling for the relevant covariates, the displaced workers would have behaved as the non-displaced in the absence of the displacement event.

\subsection{Estimations based on the JLS model}

The results from the estimation of the JLS model used in equation (1) are summarized in Figure 2. In accordance with the fixed-effects specification, the monthly earnings losses amounted to 91 percent of average pre-displacement wages 1 year after the shutdown of the firm, and decreased to 50 percent, 10 years after displacement.

The size of the loss is driven largely by the joblessness experience of the displaced workers, where, in accordance with JLS, labor earnings are taken as zero whenever the individuals are out of work. The upswing of earnings after the first year of displacement is generated mostly by the reemployment of workers. ${ }^{12}$ Note that the estimates produced by the fixed effects and the random trend models are fairly identical, as in Couch and Placzek (2010) - see Table 10 in Appendix B. In contrast with JLS, but in line with Couch and Placzek (2010), we fail to observe a severe earnings dip prior to displacement. In our individual-trend specification there is no indication that earnings had fallen before the firm closure. For the fixed-effects specification, however, there is some mild evidence that earnings fell modestly.

When we restrict our analysis to the profile of monthly wages, thereby excluding the joblessness events before and after displacement, we find that wages started declining more deeply two years before the shutdown of the firm and continued to decline for up to eight years after firm closure, remaining 12 percent below the average pre-displacement wages of the displaced (see Figure 3). At least three mechanisms may be at work. First, it may be that workers who found relatively higher wage offers returned earlier to employment. Second, longer joblessness duration may have impaired the human capital of displaced workers. And third, it may take some time for unemployed individuals to realize that their expectation about the relevant wage offer distribution

\footnotetext{
${ }^{12}$ Conditional on being displaced and returning, 14 percent of the individuals return in the first year, 16 percent return after 2 years, 14 percent return after 3 years, 13 percent return after 4 years, 10 percent return after 5 years, 9 percent return after 6 years, 8 percent return after 7 years, 8 percent return after 8 years, and 8 percent return after 9 years.
} 
Figure 2: Monthly earnings loss of displaced workers

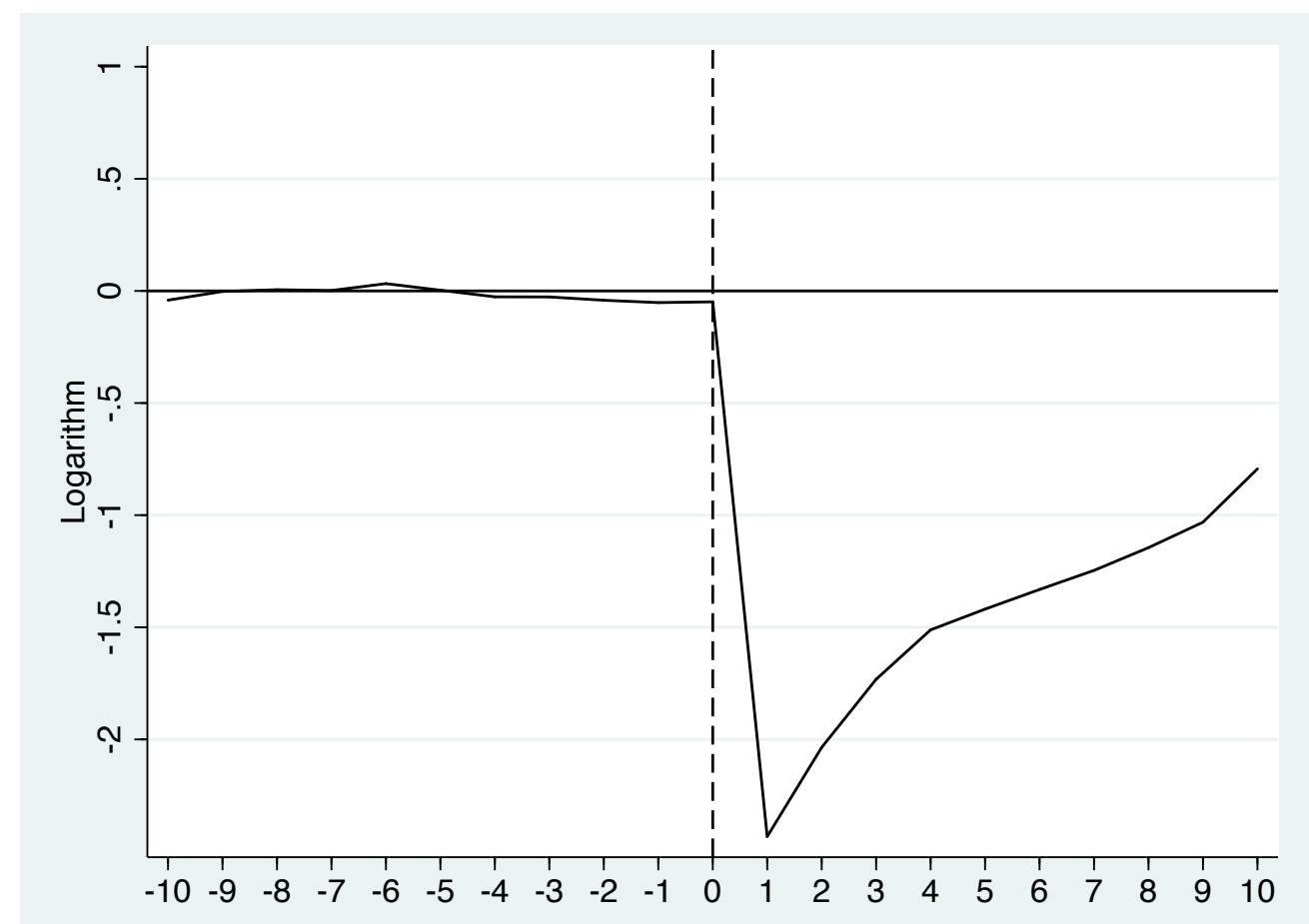

Notes: Log monthly earnings losses including transitions to zeros. On the horizontal axis the relative time to firm closure is plotted in years. In the regressions we control for age and age squared and calendar year fixed effects. See left part of Table 9 in Appendix B for the detailed results of the regressions.

is unrealistic, in particular in a labor market in which the potential duration of unemployment benefits is very generous (reaching up to 57 months of potential duration). ${ }^{13}$

\footnotetext{
${ }^{13}$ The same analysis was repeated for collective dismissals - an individual is classified as displaced due to a collective dismissal if the firm's employment dropped between year $t$ and year $t+1,30$ percent or more below its level at year $t$ (firms with fewer than 20 employees were also removed from the sample). We find broadly similar results. One year after the separation, the monthly earnings losses amounted to 92 percent of average pre-displacement wages. Conditional on returning, 13 percent of the individuals return in the first year, 15 percent return after 2 years, 13 percent return after 3 years, 12 percent return after 4 years, 11 percent return after 5 years, 9 percent return after 6 years, 9 percent return after 7 years, 9 percent return after 8 years, and 9 percent return after 9 years. Here, not even a small fall in earnings prior to separation is observed. The overall shape of the evolution of wage rates again mimics those observed for firm closures, even if the fall is not as large. Wage rates decline 7 percent for the fixed-effects model, after displacement comparing with the period before displacement.
} 
Figure 3: Monthly wage loss of displaced workers

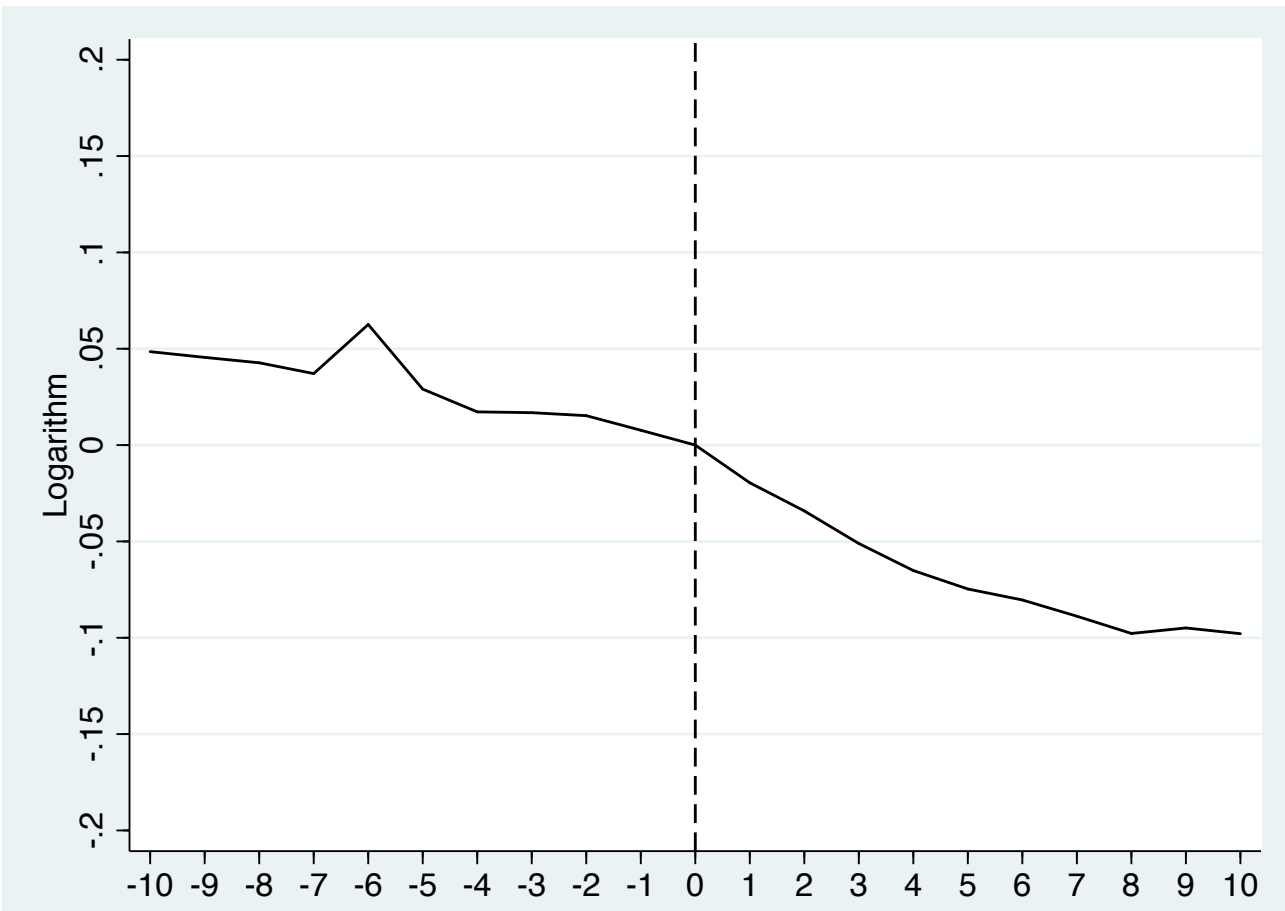

Notes: Log monthly wage losses excluding transitions to zeros. The year of firm closure is taken as the reference year ( $\delta_{k}$ is normalized to zero). On the horizontal axis the relative time to firm closure is plotted in years. In the regressions we control for age and age squared and calendar year fixed effects. See right part of Table 9 in Appendix B for the detailed results of the regressions.

\subsection{Estimations based on the three-way high-dimensional FE model}

\subsubsection{The empirical distribution of wages: pre-displacement}

To better understand the nature of the wage rate changes that affected displaced workers in comparison to non-displaced workers, we turn to the estimation of the three-way high-dimensional fixed effects regression model as given in the following equation: ${ }^{14}$

\footnotetext{
${ }^{14}$ Appendix C describes the procedure developed by Guimarães and Portugal (2010) that allows estimation of a three-way high-dimensional fixed effects model in order to obtain the estimates of worker, firm, and job title fixed effects.
} 


$$
w_{i j f t}=\alpha_{i}+\lambda_{j}+\theta_{f}+\gamma_{t}^{f u l l}+\beta^{f u l l} X_{i t}+\sum_{k \geq-m} D_{i t}^{k} \delta_{k}^{f u l l}+\epsilon_{i j f t}^{f u l l}
$$

which allows computation of the worker, firm, and job title fixed effects. The estimation is based on all the wage earners observed between 1986 and 2013, corresponding to 22,412,051 observations. The interpretation of the parameters of this model is straightforward and the decomposition exercise enabled by it, that is, the role of worker, firm, and job title heterogeneity, is discussed at length by Torres et al. (2013).

We start by graphing the empirical wage distributions of workers displaced due to firm closures and their non-displaced counterparts in Figure 4 (a). It is clear that the wages of displaced workers are lower (18 percent, on average) and less dispersed when compared with those of the non-displaced.The overall shape of the wage distribution can be better understood by looking at the distributions of the worker, firm, and job title fixed effects.

Figure 4 (b) depicts the empirical distribution of permanent worker heterogeneity, both observed (such as gender or schooling) and unobserved. A high worker fixed effect (high-wage worker) is an individual with total compensation higher than expected on the basis of observable time-varying regressors, for a given firm and job title. A distinction is made between continuing matches and those destroyed by firm closures. The graph is based on the 3,863,071 estimates of worker fixed effects. Not surprisingly, the shape of the distributions closely resembles the distributional shape of log wages. The linear correlation between log wages and worker fixed effects is 0.80 . From the comparison between displaced and non-displaced workers it is clear that those workers who exited their firms have permanent (observed and unobserved) characteristics that are associated with substantially lower wages.

Less well studied is the heterogeneity of wage policies across firms. In Figure 4 (c) we present the empirical distribution of the 76,559 firm fixed effects. A high firm fixed effect (high-wage policy from the firm) is a firm with total compensation higher than expected on the basis of observable timevarying regressors, once we take into account the (permanent) heterogeneity of workers and job titles. The role of firm heterogeneity on wage formation is quite important. The linear correlation coefficient between log wages and firm fixed effects is no less than 0.60. Not surprisingly, the comparison between the two distributions shows that displaced workers earned much lower wages in large part because the firms from which they separated exhibited a less generous wage policy.

The heterogeneity of job title fixed effects is likely to be generated by variations across occupations and skills and by differences across collective wage agreements. As discussed above, the notion of job title comes simply from the identification of distinct occupational categories within each collective wage agreement. Throughout the years of the survey we could estimate 122,647 job 
Figure 4: The empirical distribution of wages pre-displacement (reference year $D_{0}$ )
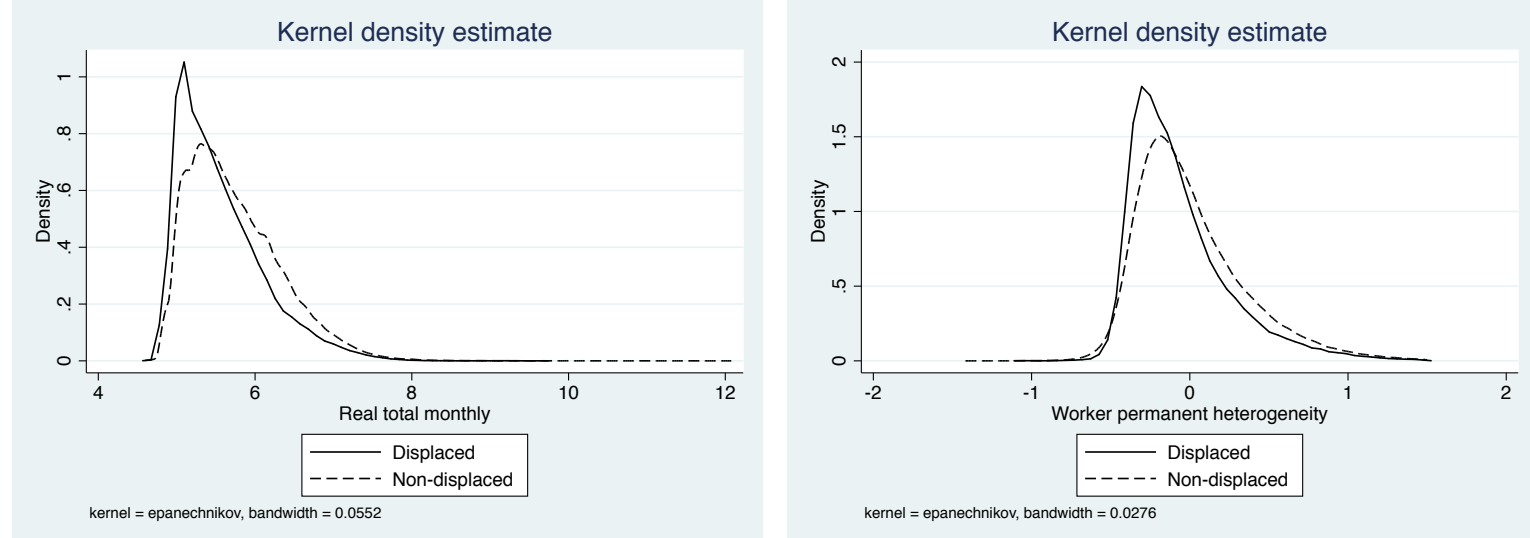

(a) Monthly wage distribution

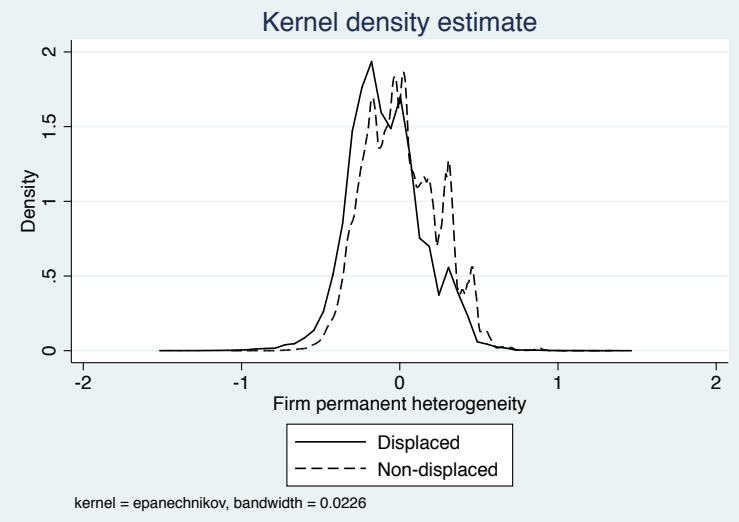

(b) Worker permanent heterogeneity

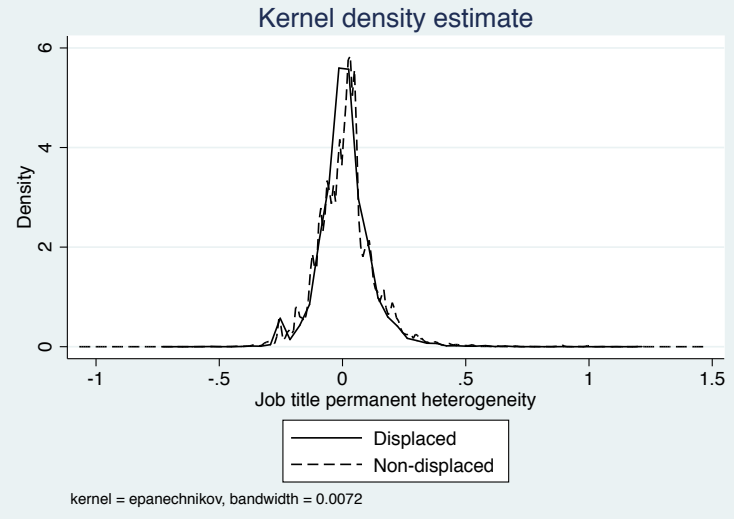

(c) Firm permanent heterogeneity

Notes: This figure plots the empirical distributions of different variables before displacement of workers displaced due to firm closures and their non-displaced counterparts (reference year $\left.D_{0}\right)$.

title fixed effects. A high job title fixed effect (job title premium) is a job title with total compensation higher than expected on the basis of observable timevarying regressors after controlling for the heterogeneity of workers and firms. Job title heterogeneity has a non-trivial impact on the determination of wages. The linear correlation between job title fixed effects and wages is a respectable 0.49. From panel (d) in Figure 4 it is clear that prior to firm closure displaced workers filled positions that were paid below those of the non-displaced. 


\subsubsection{The empirical distribution of wages of the displaced: pre- and post-displacement}

Figure 5: The empirical distribution of wages of displaced workers: pre- and post-displacement
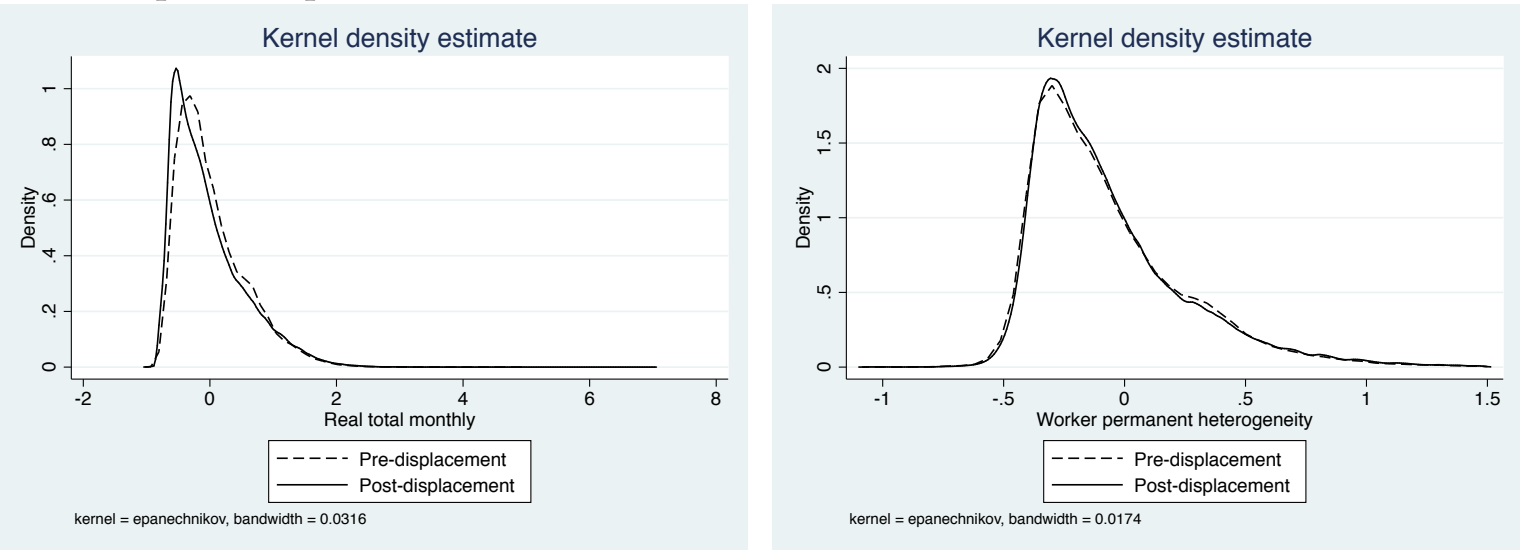

(a) Monthly wage

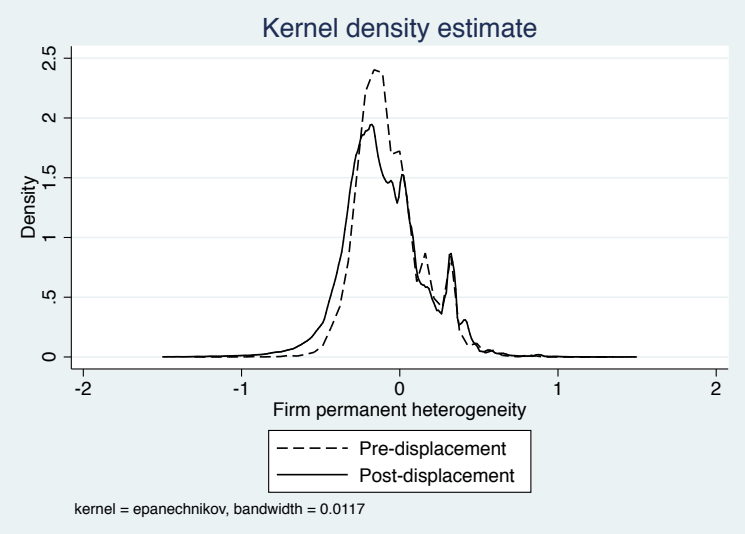

(b) Worker permanent heterogeneity

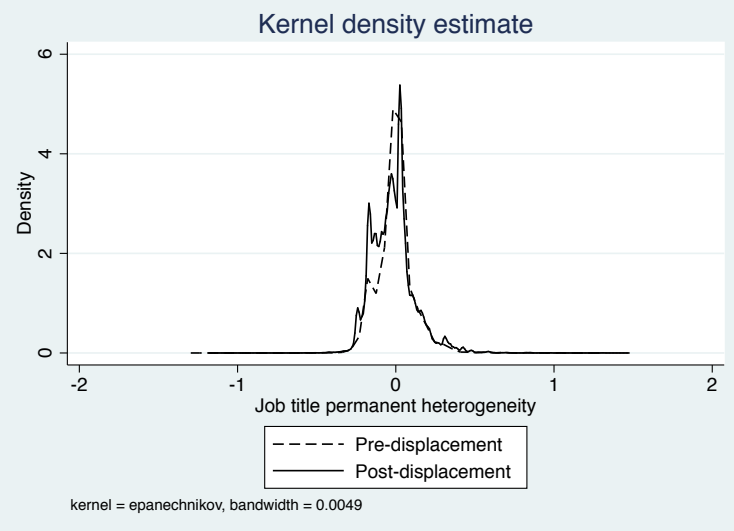

(c) Firm permanent heterogeneity

(d) Job title permanent heterogeneity

Notes: Displaced workers' density distributions before displacement and after displacement. Monthly wage in panel (a) is detrended.

In Figure 5 we compare the distribution of wages (and its components) of displaced workers based on average values before and after displacement. Panel (a) of the figure shows that the distribution of wages was shifted to the left, evincing some wage losses associated with firm closures. Panel (b) has the worker fixed effect distribution. Except for the self-selection generated by different timing of reemployment, the two distributions should coincide exactly, which for the most part they do, suggesting that the time profile of reemploy- 
ment is not a serious concern, at least in the worker heterogeneity dimension. Panels (c) and (d) both reveal that workers moved, on average, to lower paying firms and job titles, especially, in the right tail of the two distributions. Actually, 55 percent of displaced workers move to more poorly paying firms. 37 percent move to job titles that are better paid, 10 percent do not change job titles, and 53 percent move to job titles that are more poorly paid than their pre-displacement job title. ${ }^{15}$

\subsubsection{The decomposition of the wage loss}

It is possible to calculate the independent contribution of each fixed effect to the monthly wage losses of displaced workers. For this purpose we use the methodology developed in Gelbach (2016), which appeals to the omitted variables bias formula to compute a detailed decomposition. This procedure allows us to unambiguously disentangle the contribution of each excluded variable (each fixed effect) to the change in the coefficient estimate of the variables under scrutiny.

To illustrate Gelbach's decomposition, we start by defining the base model with worker fixed effects:

$$
w_{i t}=\alpha_{i}^{b a s e}+\gamma_{t}^{b a s e}+\beta^{b a s e} X_{i t}+\sum_{k \geq-m} D_{i t}^{k} \delta_{k}^{\text {base }}+\epsilon_{i t}^{\text {base }}
$$

where $\delta_{k}^{\text {base }}$ are the relevant wage loss coefficients. By excluding the firm and job title fixed effects, this equation suffers from omitted variables bias. Then, it is necessary to specify the full model with the two fixed effects as in equation (2).

The base-full difference equals the sample analog of the omitted variables bias formula. Gelbach's algorithm allows us to decompose the difference $\delta_{k}^{b a s e}$ $\delta_{k}^{f u l l}$ into the separate effect deriving from each excluded variable (each fixed effect). The algorithm is as follows:

Step 1. Use OLS to estimate the vector of coefficients in equation (3). Extract $\delta_{k}^{\text {base }}$;

Step 2. Use OLS to estimate the vector of coefficients in equation (2). Extract $\delta_{k}^{\text {full }}$;

Step 3. Use a set of two auxiliary regressions for $\hat{\lambda}_{j}$ and $\hat{\theta}_{f}$ acting now as the dependent variables and where all the other variables in equation (2) are used as explanatory variables, that is on $X_{i t}$ and $D_{i t}^{k}$;

\footnotetext{
${ }^{15}$ Displaced workers are more likely to be confronted by job title downgrades than job title upgrades. We had a close look to the more frequent job title moves among displaced workers. However, given the unusually high level of disaggregation, it is very hard to establish clear patterns of job title movements. Some illustrative changes can, nevertheless reveal the job title dynamics. For example, we observe a significant number of truck drivers becoming car drivers, earlier dress makers working as janitors, and shoemakers converting to cloth-workers.
} 
Step 4. Extract the coefficients on $D_{i t}^{k}$ and denote them as $\hat{\tau}_{k}^{\lambda}$ and $\hat{\tau}_{k}^{\theta}$, respectively, for each of the fixed effects.

Step 5. Verify that the equality $\delta_{k}^{\text {base }}-\delta_{k}^{f u l l}=\hat{\tau}_{k}^{\lambda}+\hat{\tau}_{k}^{\theta}$ holds, for each time period $k$.

In summary, the decomposition proposed by Gelbach is a computationally simple and econometrically meaningful procedure that takes advantage, in a surprisingly ingenious way, of the conventional OLS omitted variable bias formula. If the base specification is a parsimonious useful benchmark, and in our case it is simply a conditional gross measure of the displacement wage rate losses, the decomposition is also economically meaningful, providing an unambiguous measure of the contribution of each omitted variable to the change in the original coefficients of the displacement dummies. For example, the fact that the inclusion of firm fixed effects contributes to decreasing the wage loss of displaced workers, simply accounts for the evidence that displaced workers tend to sort themselves into firms that pay, on average, lower wages. When we compare the impact of firm fixed effects before and after displacement, we are simply isolating the dominant influence of movements from higher paying firms into lower paying firms. A similar interpretation applies to the role of job title fixed effects.

The results of the Gelbach decomposition are reported in Table 3. The first two columns of the table give the coefficient estimates for the benchmark OLS regression with worker fixed effects (base model) and for a regression that includes, in addition, the three fixed effects (full model). Recall that in the fixed effects model, the estimates of the coefficients of the displacement dummies do not have a straightforward interpretation in terms of wage losses of displaced workers relative to non-displaced workers, since the coefficients represent within-individual wage changes over time.

Hence, according to the base model estimates and turning our attention to average differences in the periods before and after displacement (last line), we conclude that post-displacement wages are $10 \mathrm{log}$ points lower than predisplacement wages, i.e., 9.5 percent less than average pre-displacement wages. Once we account for firm and job title fixed effects, the remaining unexplained difference in wages falls to $2.6 \mathrm{log}$ points. This means that the inclusion of the fixed effects accounts for $7.4 \mathrm{log}$ points of the difference between the wages before and after displacement, where $4.2 \log$ points are accounted for by the firm fixed effect, and $3.2 \log$ points are accounted for by the job title fixed effect. 
Table 3: Decomposition of the wage loss - firm and job title

\begin{tabular}{|c|c|c|c|c|c|}
\hline $\begin{array}{r}\text { Period } \\
\text { relative } \\
\text { to displacement } \\
\end{array}$ & Base & Full & $\delta_{k}^{\text {base }}-\delta_{k}^{\text {full }}$ & $\begin{array}{c}\text { Firm } \\
\text { fixed effect }\end{array}$ & $\begin{array}{l}\text { Job title } \\
\text { fixed effect }\end{array}$ \\
\hline$D_{-10}$ & 0.105 & 0.016 & 0.088 & 0.043 & 0.045 \\
\hline$D_{-9}$ & 0.102 & 0.012 & 0.089 & 0.045 & 0.044 \\
\hline$D_{-8}$ & 0.099 & 0.014 & 0.084 & 0.043 & 0.041 \\
\hline$D_{-7}$ & 0.093 & 0.010 & 0.083 & 0.045 & 0.038 \\
\hline$D_{-6}$ & 0.119 & 0.033 & 0.086 & 0.046 & 0.040 \\
\hline$D_{-5}$ & 0.085 & 0.001 & 0.084 & 0.046 & 0.038 \\
\hline$D_{-4}$ & 0.073 & -0.008 & 0.082 & 0.045 & 0.037 \\
\hline$D_{-3}$ & 0.073 & -0.008 & 0.081 & 0.044 & 0.037 \\
\hline$D_{-2}$ & 0.071 & -0.006 & 0.077 & 0.042 & 0.035 \\
\hline$D_{-1}$ & 0.064 & -0.012 & 0.076 & 0.042 & 0.034 \\
\hline$D_{0}$ & 0.056 & -0.020 & 0.076 & 0.043 & 0.034 \\
\hline$D_{1}$ & 0.037 & -0.025 & 0.062 & 0.035 & 0.027 \\
\hline$D_{2}$ & 0.022 & -0.022 & 0.044 & 0.024 & 0.020 \\
\hline$D_{3}$ & 0.005 & -0.024 & 0.029 & 0.015 & 0.015 \\
\hline$D_{4}$ & -0.009 & -0.026 & 0.017 & 0.006 & 0.010 \\
\hline$D_{5}$ & -0.019 & -0.025 & 0.007 & 0.001 & 0.006 \\
\hline$D_{6}$ & -0.024 & -0.022 & -0.002 & -0.005 & 0.003 \\
\hline$D_{7}$ & -0.033 & -0.022 & -0.011 & -0.010 & -0.001 \\
\hline$D_{8}$ & -0.042 & -0.023 & -0.019 & -0.014 & -0.005 \\
\hline$D_{9}$ & -0.039 & -0.019 & -0.020 & -0.011 & -0.009 \\
\hline$D_{10}$ & -0.042 & -0.018 & -0.023 & -0.017 & -0.007 \\
\hline$\mu_{\text {Pre-displacement }}$ & 0.086 & 0.003 & 0.082 & 0.044 & 0.038 \\
\hline$\mu_{\text {Post-displacement }}$ & -0.014 & -0.023 & 0.008 & 0.002 & 0.006 \\
\hline$\Delta$ & -0.100 & -0.026 & -0.074 & -0.042 & -0.032 \\
\hline
\end{tabular}

Notes: This table reports the Gelbach decomposition of the two fixed effects of the wage loss of displaced workers (log monthly wage). In the regressions we control for age, age squared, and calendar year fixed effects. All regressions are computed with worker fixed effects. In each column $\mu_{\text {Pre-displacement }}$ is the computed average between the first eleven lines $\left(D_{-10}\right.$ to $\left.D_{0}\right) . \mu_{\text {Post-displacement is the computed average between the next ten lines }}$ $\left(D_{1}\right.$ to $\left.D_{10}\right)$. In the line $\Delta$ we compute the difference between the previous two lines.

In this setup, the most important factor driving the wage penalty of these displaced workers is the fact that they are reemployed in firms that have less generous wage policies, accounting for 57 percent of the total explained average wage loss. This result seems also to indicate that low-paying firms are the most 
likely port of re-entry into employment for displaced workers. The fact that these workers are reemployed in job categories (and/or collective agreements) that are less generously remunerated also plays an important role. ${ }^{16}$ The unfavorable allocation into job titles accounts for roughly 43 percent of the total average wage loss. ${ }^{17}$

\subsection{Assessing the role of worker-firm match quality}

As discussed above, in this framework it is important to distinguish a good worker in a good firm from a good worker-firm match. To allow for the possibility that there are some observed and unobserved permanent worker-firm match heterogeneities that constitute important determinants of wages, following Woodcock (2008), we incorporate an additional term in the regression $\left(\psi_{i f}\right)$, which now also incorporates the interaction between worker and firm. This extension is applied to the monthly wage discarding observations in which labor earnings are zero. The full baseline specification is given by Equation (4a).

$$
w_{i j f t}=\alpha_{i}+\lambda_{j}+\theta_{f}+\psi_{i f}+\gamma_{t}+\beta X_{i t}+\sum_{k \geq-m} D_{i t}^{k} \delta_{k}+\epsilon_{i t}
$$

However, this model is overparameterized, making it impossible to disentangle the four effects. In this model, the quality of the worker-firm match is indistinguishable from a good employee working in a good firm. In other words, without any restriction on the parameters, $\psi_{i f}$ absorbs the effect of $\alpha_{i}$ and $\theta_{f}$, meaning that a model with a single worker-firm match term $\left(\omega_{i f}\right)$ will capture the three effects and provide the same fit as equation (4a).

$$
w_{i j f t}=\omega_{i f}+\lambda_{j}+\gamma_{t}+\beta X_{i t}+\sum_{k \geq-m} D_{i t}^{k} \delta_{k}+\epsilon_{i t}
$$

Nevertheless, we are interested in the relationship between $\psi_{i f}$ and $\delta_{k}$ after controlling for all other explanatory variables in equation (4a). Fortunately, Figueiredo et al. (2014) show that the impact of match quality $\left(\psi_{i f}\right)$ can be extracted from a regression of $\omega_{i f}$ on firm and worker fixed effects plus the other regressors in the base specification. Alternatively, the same estimate can be obtained directly by comparing the estimated coefficients of equations (2) and (5).

\footnotetext{
${ }^{16}$ The wage change (in particular that associated with the job title and the firm fixed effect) can be generated by rents or compensating wage differentials, as discussed above. In the first case a wage drop after displacement can be interpreted as a welfare loss to the worker, in the second case there may be no welfare loss.

${ }^{17}$ When we repeat the same analysis using before and after instead of the yearly dummies, respectively $D_{-10}-D_{0}$ and $D_{1}$ to $D_{10}$, we find broadly comparable results. Workers in our sample faced a wage penalty of $9 \log$ points. The two fixed effects account for $7 \log$ points of the total loss, which can be disentangled as 4 log points due to sorting into lower paying firms, and $3 \log$ points due to sorting into lower paying job titles.
} 
Table 4: Decomposition of the wage loss - firm, worker-firm match and job title

\begin{tabular}{|c|c|c|c|c|c|c|}
\hline $\begin{array}{r}\text { Period } \\
\text { relative } \\
\text { to displacement }\end{array}$ & Base & Full & $\delta_{k}^{\text {base }}-\delta_{k}^{\text {full }}$ & $\begin{array}{c}\text { Firm } \\
\text { fixed effect }\end{array}$ & $\begin{array}{c}\text { Match } \\
\text { fixed effect }\end{array}$ & $\begin{array}{l}\text { Job title } \\
\text { fixed effect }\end{array}$ \\
\hline$D_{-10}$ & 0.105 & -0.011 & 0.116 & 0.043 & 0.031 & 0.042 \\
\hline$D_{-9}$ & 0.102 & -0.016 & 0.118 & 0.045 & 0.031 & 0.042 \\
\hline$D_{-8}$ & 0.099 & -0.015 & 0.114 & 0.043 & 0.032 & 0.039 \\
\hline$D_{-7}$ & 0.093 & -0.019 & 0.113 & 0.045 & 0.032 & 0.035 \\
\hline$D_{-6}$ & 0.119 & 0.004 & 0.115 & 0.046 & 0.032 & 0.037 \\
\hline$D_{-5}$ & 0.085 & -0.029 & 0.114 & 0.046 & 0.033 & 0.036 \\
\hline$D_{-4}$ & 0.073 & -0.038 & 0.111 & 0.045 & 0.032 & 0.034 \\
\hline$D_{-3}$ & 0.073 & -0.038 & 0.111 & 0.044 & 0.033 & 0.033 \\
\hline$D_{-2}$ & 0.071 & -0.036 & 0.107 & 0.042 & 0.033 & 0.032 \\
\hline$D_{-1}$ & 0.064 & -0.041 & 0.105 & 0.042 & 0.032 & 0.031 \\
\hline$D_{0}$ & 0.056 & -0.049 & 0.105 & 0.043 & 0.032 & 0.030 \\
\hline$D_{1}$ & 0.037 & -0.020 & 0.057 & 0.035 & -0.002 & 0.024 \\
\hline$D_{2}$ & 0.022 & -0.012 & 0.034 & 0.024 & -0.007 & 0.017 \\
\hline$D_{3}$ & 0.005 & -0.012 & 0.017 & 0.015 & -0.011 & 0.013 \\
\hline$D_{4}$ & -0.009 & -0.012 & 0.003 & 0.006 & -0.012 & 0.008 \\
\hline$D_{5}$ & -0.019 & -0.010 & -0.009 & 0.001 & -0.014 & 0.004 \\
\hline$D_{6}$ & -0.024 & -0.006 & -0.018 & -0.005 & -0.015 & 0.002 \\
\hline$D_{7}$ & -0.033 & -0.005 & -0.028 & -0.010 & -0.016 & -0.001 \\
\hline$D_{8}$ & -0.042 & -0.005 & -0.037 & -0.014 & -0.018 & -0.005 \\
\hline$D_{9}$ & -0.039 & -0.002 & -0.037 & -0.011 & -0.018 & -0.008 \\
\hline$D_{10}$ & -0.042 & -0.004 & -0.038 & -0.017 & -0.015 & -0.006 \\
\hline$\mu_{\text {Pre-displacement }}$ & 0.086 & -0.026 & 0.112 & 0.044 & 0.032 & 0.035 \\
\hline$\mu_{\text {Post-displacement }}$ & -0.014 & -0.009 & -0.006 & 0.002 & -0.013 & 0.005 \\
\hline$\Delta$ & -0.100 & 0.017 & -0.117 & -0.042 & -0.045 & -0.030 \\
\hline
\end{tabular}

Notes: This table reports the Gelbach decomposition of the two fixed effects of the wage loss of displaced workers. In the regressions we control for age, age squared, and calendar year fixed effects. All regressions are computed with worker fixed effects. In each column $\mu_{P r e-\text { displacement }}$ is the computed average between the first

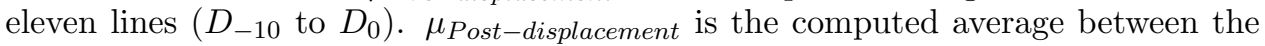
next ten lines $\left(D_{1}\right.$ to $\left.D_{10}\right)$. In the line $\Delta$ we compute the difference between the previous two lines.

We next introduce a worker-firm specific fixed effect that accounts for match heterogeneity. This match effect absorbs the worker and the firm individual fixed effects. We can conclude that the worker-firm match quality is responsible for a sizable $4.5 \log$ points of the wage loss, the firms fixed effects accounts for 
$4.2 \log$ points and the job title fixed effect for the remaining $3.0 \log$ points of the total explained wage loss.

In sum, controlling for the worker-firm match, we find that the latter accounts for 38 percent of the total wage loss, allocation into unfavaroble job titles accounts for 26 percent, and the remaining 36 percent could be attributed to firm fixed effects. Thus, failure to account for match effects largely overestimates the role of the reallocation of workers into firms and job titles in explaining the wage losses of the displaced. ${ }^{18}$

\subsection{Assessing the role of the bargained wage}

In this section we split the wage rate into two components, the bargained wage and the wage cushion, and proceed, as before, with the Gelbach decomposition exercise. The bargained wage corresponds to the wage floor negotiated (typically at the industry level) between the trade unions and employers' associations for each job title. Firms often pay wages above this floor (as discussed above), leading to a gap between the actual wage paid and the bargained wage, which we call the wage cushion. Because we can not directly observe the bargained wage we compute for each job title (in any given year) the modal base wage and used it as a proxy for the collectively agreed wage, a methodology identical to the one pursued by Cardoso and Portugal (2005).

Table 5 shows the results of the exercise for the bargained wage. A useful way to look at the decompositions is to think of an artificial situation in which all workers simply collect the bargained wage corresponding to their job titles. In this case, the wage loss of the displaced workers would be generated by changes in the (imputed) remuneration of job titles, before and after displacement. The results indicate that job downgrading plays a very important role, implying a loss of 7 percent. In other words, if workers receive exactly the bargained wage, the wage loss of displaced workers would have been, on average, 7 percent. By construction, in this decomposition there is no role for the allocation of displaced workers among firms, and indeed, the estimated impact of the wage policy of the firms is negligible.

The wage policy of the firms is much more important in the determination of the wage cushion. Table 6 shows that displaced workers are allocated to relatively less-generous firms in terms of the wage cushion, implying a wage loss of around 3.8 percent. Displaced workers are allocated to relatively better paying job titles in terms of the wage cushion, partially offsetting (by 3.7 percent) the loss in terms of the bargained wage. In this set-up, a loss of 2.8

\footnotetext{
${ }^{18}$ When we repeat the same analysis for collective dismissals, we find broadly comparable results. Workers in our sample affected by collective dismissals faced a somewhat lower wage penalty ( $8 \mathrm{log}$ points) than those that suffered from a firm closure (10 log points) - see Appendix D. The allocation into firms with different wage policies is the most influential factor, accounting for 45 percent of the total average loss. Sorting into job titles explains 20 percent of the loss. Worker-firm match explains 35 percent of the total average loss.
} 
percent remains unexplained.

Overall, the decompositions for the bargained wage and the wage cushion are coherent with the decomposition of the total wage provided in Table 3. The unexplained sources of wage losses and those related with firm allocation are rooted solely in the determination of the wage cushion. The wage losses associated with the allocation among job titles, however, are negatively affected by the bargained wage and positively affected by the wage cushion. 
Table 5: Decomposition of the bargained wage

\begin{tabular}{|c|c|c|c|c|c|}
\hline $\begin{array}{r}\text { Period } \\
\text { relative } \\
\text { to displacement }\end{array}$ & Base & Full & $\delta_{k}^{\text {base }}-\delta_{k}^{\text {full }}$ & $\begin{array}{c}\text { Firm } \\
\text { fixed effect }\end{array}$ & $\begin{array}{l}\text { Job title } \\
\text { fixed effect }\end{array}$ \\
\hline$D_{-10}$ & 0.070 & -0.003 & $0.073^{n}$ & 0.004 & 0.068 \\
\hline$D_{-9}$ & 0.072 & -0.003 & 0.076 & 0.005 & 0.071 \\
\hline$D_{-8}$ & 0.067 & -0.006 & 0.073 & 0.005 & 0.067 \\
\hline$D_{-7}$ & 0.062 & -0.010 & 0.071 & 0.006 & 0.065 \\
\hline$D_{-6}$ & 0.066 & -0.010 & 0.075 & 0.006 & 0.069 \\
\hline$D_{-5}$ & 0.069 & -0.008 & 0.077 & 0.007 & 0.070 \\
\hline$D_{-4}$ & 0.068 & -0.009 & 0.077 & 0.008 & 0.069 \\
\hline$D_{-3}$ & 0.068 & -0.009 & 0.077 & 0.008 & 0.069 \\
\hline$D_{-2}$ & 0.062 & -0.011 & 0.073 & 0.008 & 0.065 \\
\hline$D_{-1}$ & 0.060 & -0.014 & 0.074 & 0.007 & 0.067 \\
\hline$D_{0}$ & 0.055 & -0.015 & 0.070 & 0.008 & 0.062 \\
\hline$D_{1}$ & 0.035 & -0.010 & 0.045 & 0.006 & 0.039 \\
\hline$D_{2}$ & 0.014 & -0.010 & 0.024 & 0.004 & 0.020 \\
\hline$D_{3}$ & 0.002 & -0.008 & 0.010 & 0.004 & 0.006 \\
\hline$D_{4}$ & -0.001 & -0.008 & 0.007 & 0.003 & 0.004 \\
\hline$D_{5}$ & -0.002 & -0.006 & 0.003 & 0.003 & 0.001 \\
\hline$D_{6}$ & -0.008 & -0.007 & -0.001 & 0.002 & -0.004 \\
\hline$D_{7}$ & -0.014 & -0.006 & -0.008 & 0.002 & -0.010 \\
\hline$D_{8}$ & -0.027 & -0.005 & -0.022 & 0.002 & -0.024 \\
\hline$D_{9}$ & -0.024 & -0.003 & -0.022 & 0.004 & -0.025 \\
\hline$D_{10}$ & -0.028 & -0.003 & -0.025 & 0.003 & -0.028 \\
\hline$\mu_{\text {Pre-displacement }}$ & 0.065 & -0.009 & 0.074 & 0.007 & 0.068 \\
\hline$\mu_{\text {Post-displacement }}$ & -0.005 & -0.007 & 0.001 & 0.003 & -0.002 \\
\hline$\Delta$ & -0.071 & 0.002 & -0.073 & -0.003 & -0.070 \\
\hline
\end{tabular}

Notes: This table reports the Gelbach decomposition of the two fixed effects of the wage loss of displaced workers. In the regressions we control for age, age squared, and calendar year fixed effects. All regressions are computed with worker fixed effects. In each column $\mu_{\text {Pre-displacement }}$ is the computed average between the first eleven lines $\left(D_{-10}\right.$ to $\left.D_{0}\right) . \mu_{\text {Post-displacement }}$ is the computed average between the next six lines $\left(D_{1}\right.$ to $\left.D_{10}\right)$. In the line $\Delta$ we compute the difference between the previous two lines. 
Table 6: Decomposition of the wage cushion

\begin{tabular}{|c|c|c|c|c|c|}
\hline $\begin{array}{r}\text { Period } \\
\text { relative } \\
\text { to displacement }\end{array}$ & Base & Full & $\delta_{k}^{\text {base }}-\delta_{k}^{\text {full }}$ & $\begin{array}{c}\text { Firm } \\
\text { fixed effect }\end{array}$ & $\begin{array}{c}\text { Job title } \\
\text { fixed effect }\end{array}$ \\
\hline$D_{-10}$ & 0.034 & 0.019 & 0.015 & 0.039 & -0.024 \\
\hline$D_{-9}$ & 0.028 & 0.015 & 0.013 & 0.040 & -0.026 \\
\hline$D_{-8}$ & 0.031 & 0.019 & 0.012 & 0.038 & -0.026 \\
\hline$D_{-7}$ & 0.031 & 0.019 & 0.012 & 0.040 & -0.027 \\
\hline$D_{-6}$ & 0.052 & 0.042 & 0.010 & 0.039 & -0.029 \\
\hline$D_{-5}$ & 0.016 & 0.009 & 0.007 & 0.039 & -0.032 \\
\hline$D_{-4}$ & 0.005 & 0.000 & 0.005 & 0.037 & -0.032 \\
\hline$D_{-3}$ & 0.005 & 0.001 & 0.004 & 0.036 & -0.032 \\
\hline$D_{-2}$ & 0.009 & 0.005 & 0.004 & 0.034 & -0.030 \\
\hline$D_{-1}$ & 0.004 & 0.002 & 0.002 & 0.034 & -0.033 \\
\hline$D_{0}$ & 0.001 & -0.006 & 0.006 & 0.035 & -0.029 \\
\hline$D_{1}$ & 0.001 & -0.015 & 0.016 & 0.028 & -0.012 \\
\hline$D_{2}$ & 0.006 & -0.013 & 0.019 & 0.020 & -0.001 \\
\hline$D_{3}$ & 0.003 & -0.016 & 0.019 & 0.011 & 0.008 \\
\hline$D_{4}$ & -0.008 & -0.017 & 0.009 & 0.003 & 0.006 \\
\hline$D_{5}$ & -0.016 & -0.020 & 0.003 & -0.002 & 0.005 \\
\hline$D_{6}$ & -0.017 & -0.016 & -0.001 & -0.008 & 0.006 \\
\hline$D_{7}$ & -0.020 & -0.017 & -0.002 & -0.012 & 0.010 \\
\hline$D_{8}$ & -0.015 & -0.018 & 0.003 & -0.016 & 0.018 \\
\hline$D_{9}$ & -0.015 & -0.016 & 0.002 & -0.013 & 0.015 \\
\hline$D_{10}$ & -0.014 & -0.016 & 0.002 & -0.019 & 0.020 \\
\hline$\mu_{\text {Pre-displacement }}$ & 0.020 & 0.011 & 0.008 & 0.037 & -0.029 \\
\hline$\mu_{\text {Post-displacement }}$ & -0.010 & -0.016 & 0.007 & -0.001 & 0.008 \\
\hline$\Delta$ & -0.029 & -0.028 & -0.001 & -0.038 & 0.037 \\
\hline
\end{tabular}

Notes: This table reports the Gelbach decomposition of the two fixed effects of the wage loss of displaced workers. In the regressions we control for age, age squared, and calendar year fixed effects. All regressions are computed with worker fixed effects. In each column $\mu_{\text {Pre-displacement }}$ is the computed average between the first eleven lines $\left(D_{-10}\right.$ to $\left.D_{0}\right) . \mu_{\text {Post-displacement }}$ is the computed average between the next six lines $\left(D_{1}\right.$ to $\left.D_{10}\right)$. In the line $\Delta$ we compute the difference between the previous two lines.

\subsection{Assessing the role of permanent observed heterogeneity}

In a fixed effects approach, worker, firm, and job title fixed effects may include two components - unobserved and observed time-invariant characteristics. Re- 
Table 7: Assessing the role of permanent observed heterogeneity

\begin{tabular}{lccc} 
& $\begin{array}{c}\Delta \text { Firm } \\
\text { fixed effect }\end{array}$ & $\begin{array}{c}\Delta \text { Job title } \\
\text { fixed effect }\end{array}$ \\
\hline Change industry 2 digits & $-0.029^{* * *}$ & Change occupation (5 digits) & $-0.003^{* * *}$ \\
& $(0.004)$ & & $(0.001)$ \\
Change firm size (log) & $0.040^{* * *}$ & Change collective agreement & $0.008^{* * *}$ \\
& $(0.002)$ & & $(0.001)$ \\
Change single to multi-plant & 0.008 & Tenure (previous job) & $-0.026^{* * *}$ \\
& $(0.006)$ & $(0.001)$ \\
Change public to private capital & $-0.024^{* * *}$ & Tenure squared & $0.005^{* * *}$ \\
& $(0.007)$ & & $(0.000)$ \\
Change domestic to foreign capital & $0.035^{* * *}$ & & \\
& $(0.004)$ & & \\
Change region & -0.001 & & \\
& $(0.004)$ & & $0.018^{* * *}$ \\
Constant & $-0.047^{* *}$ & $(0.004)$ \\
& $(0.022)$ & \\
Observations & 111,779 & 111,779 \\
R-squared & 0.123 & 0.046 \\
\hline
\end{tabular}

Notes: In the regressions we control for calendar year fixed effects. All the explanatory variables except tenure are defined by comparing job and firm characteristics of the displaced in the last record before $\left(D_{0}\right)$ and after displacement. Tenure in the previous job is measured in $D_{0}$. Robust standard errors in parentheses. $* * * \mathrm{p}<0.01,{ }^{*} \mathrm{p}<0.05,{ }^{*} \mathrm{p}<0.1$

garding the latter, it seems natural to ask how observed components are related to changes in the firm and job title fixed effects after displacement. For that purpose we ran two separate OLS regressions using the sample of displaced workers that were re-employed during the period analyzed, i.e., 111,779 displaced workers after excluding those observations with missing values in the explanatory variables. The results are reported in Table 7 .

In the first regression (see left part of Table 7) the dependent variable is defined as the change in the firm fixed effect in the period after displacement relative to the period before displacement. Firm observed characteristics include industry, size (measured by the number of employees and the number of establishments), ownership type (public or private/foreign or domestic), and location. ${ }^{19}$

In the second regression (see right part of Table 7) the dependent variable is defined as the change in the job title fixed effect after displacement. Job title observed characteristics include tenure, occupation, and collective agreement.

The estimates show that a change in industry, firm size, and ownership type play a non-trivial role in driving the change in the firm fixed effect. Further-

\footnotetext{
${ }^{19}$ See Abowd et al. (1999) for a discussion of the relationship between pure firm effects and pure industry and firm-size effects.
} 
more, the three most important observed characteristics of the job - occupation, collective agreement, and tenure - are all statistically significant at the conventional levels. A change in the 5 digits occupation and the loss of tenure in the previous job are related to sorting into a low-paying job title, while a change in the collective agreement is related to sorting into a high-paying job. These results are not unexpected and reinforce the role of job downgrading in explaining the subsequent wage losses due to displacement.

Finally, the results also show that a large component of the change in the fixed effects after displacement should be attributed to unobserved firm and job title characteristics.

\section{Concluding remarks}

Wage losses of displaced workers can be related to the firm, job title, and the worker-firm match that existed before and after displacement. In this paper we first explored the sources of those losses, estimating a three-way high-dimensional fixed effects regression model, which enabled us to obtain worker, firm, and job title fixed effects. To decompose the wage losses into the contribution of each fixed effect, we implemented the conditional decomposition method suggested by Gelbach (2016).

Based on the JLS methodology, we found that post-displacement wages are, on average, 9.5 percent lower than pre-displacement wages. Sorting into matches plays a very sizable role in explaining these losses, accounting for around 39 percent of the total average wage loss for workers displaced through firm closures. The allocation into lower-paid job titles also plays a significant role, accounting for around 26 percent of the total average wage loss. Firm fixed effects account for the remaining 35 percent. Furthermore, based on the way those job titles were identified - from a combination of occupation and collective agreement - we examined how observed components of the job title are related to those losses. The results seem to show that job downgrading after displacement is driven mainly by human capital depreciation, which can be traced through the job title fixed effects, in terms of losses of job specific training and occupation specific human capital. Sizable industry specific losses of human capital can also be spotted along the distributional changes of firm fixed effects.

There are some potentially important policy prescriptions that may be derived from the evidence reported in this study. Severe losses in the returns to the job title may represent a job downgrading due to depreciation of general and specific human capital or to the difficulty of finding a new job requiring skills similar to those acquired in the pre-displacement job. Here, retraining programs may be of some help.

Losses related with the firm/worker-firm match fixed effect may mean that a worker is moving from a high paying firm/high-quality match to a low-paying 
fim/low-quality match. Actually, with the occurrence of a displacement event, successful job searchers may lose their "job shopping" investment (Johnson (1978)). If this phenomenon is pervasive, job search assistance programs and mandatory pre-notification of impending redundancy may be justified. 


\section{References}

Abowd, J., Creecy, R., and Kramarz, F. (2002). Computing person and firm effects using linked longitudinal employer-employee data. Technical Papers 2002-06, Longitudinal Employer-Household Dynamics, Center for Economic Studies, U.S. Census Bureau.

Abowd, J., Kramarz, F., and Margolis, D. (1999). High wage workers and high wage firms. Econometrica, 67(2):251-334.

Abraham, K. and Farber, H. (1988). Returns to seniority in union and nonunion jobs: A new look at the evidence. Industrial and Labor Relations Review, 42(1):3-19.

Abraham, K. G. and Farber, H. S. (1987). Job duration, seniority, and earnings. American Economic Review, 77(3):278-97.

Addison, J. T. and Portugal, P. (1987). On the distributional shape of unemployment duration. The Review of Economics and Statistics, 69(3):521-26.

Altonji, J. and Shakotko, R. (1987). Do wages rise with job seniority? Review of Economic Studies, 54(3):437-59.

Blanchard, O. and Portugal, P. (2001). What hides behind an unemployment rate: Comparing Portuguese and U.S. labor markets. The American Economic Review, 91(1):187-207.

Burda, M. and Mertens, A. (2001). Estimating wage losses of displaced workers in Germany. Labour Economics, 8(1):15 - 41.

Burdett, K. and Mortensen, D. T. (1998). Wage differentials, employer size, and unemployment. International Economic Review, 39(2):257-273.

Cardoso, A. R. (2000). Wage differentials across firms: an application of multilevel modelling. Journal of Applied Econometrics, 15:343-354.

Cardoso, A. R. and Portugal, P. (2005). Contractual wages and the wage cushion under different bargaining settings. Journal of Labor Economics, $23(4): 875-874$.

Carneiro, A., Portugal, P., and Varejão, J. (2014). Catastrophic job Destruction during the Portuguese Economic Crisis. Journal of Macroeconomics, 39:444457.

Carrington, W. J. and Fallick, B. C. (2014). Why Do Earnings Fall with Job Displacement? Working Paper 1405, Federal Reserve Bank of Cleveland.

Couch, K. and Placzek, D. (2010). Earnings losses of displaced workers revisited. American Economic Review, 100(1):572-89. 
Davis, S. J. and von Wachter, T. (2011). Recessions and the cost of job loss. NBER Working Papers 17638, National Bureau of Economic Research, Inc.

Dustmann, C. and Meghir, C. (2005). Wages, experience and seniority. Review of Economic Studies, 72(1):77-108.

Figueiredo, O., Guimarães, P., and Woodward, D. (2014). Firm-worker matching in industrial clusters. Journal of Economic Geography, 14(1):1-19.

Garda, P. (2012). Wage losses after displacement in Spain. the role of specific human capital. Mimeo.

Gelbach, J. (2016). When do covariates matter? And which ones, and how much? Journal of Labor Economics, 34(2):forthcoming.

Goux, D. and Maurin, E. (1999). Persistence of interindustry wage differentials: a reexamination using matched worker-firm panel data. Journal of Labor Economics, 17(3):492-533.

Guimarães, P. and Portugal, P. (2010). A simple feasible procedure to fit models with high-dimensional fixed effects. Stata Journal, 10(4):628-649.

Hamermesh, D. S. (1987). The costs of worker displacement. The Quarterly Journal of Economics, 102(1):51-75.

Hamermesh, D. S. (1989). What do we know about worker displacement in the U.S. Industrial Relations, 12(1):51-59.

Hartog, J., Pereira, P., and Vieira, J. (2002). Bargaining regimes and wages in Portugal. Portuguese Economic Journal, 1(3):237-268.

Johnson, W. R. (1978). A theory of job shopping. The Quarterly Journal of Economics, 92(2):261-78.

Kambourov, G. and Manovskii, I. (2009). Human capital specificity: evidence from the dictionary of occupational titles and displaced worker surveys, 19842000. International Economic Review, 50(1):63-115.

Kletzer, L. (1998). Job displacement. Journal of Economic Perspectives, 12(1):115-36.

Manning, A. (2003). Monopsony in motion: Imperfect competition in labor markets. Princeton University Press.

Manning, A. (2011). Imperfect competition in the labor market, volume 4 of Handbook of Labor Economics, pages 973-1041. Elsevier. 
Martins, P. S. (2014). 30,000 minimum wages: The economic effects of collective agreement extensions. Working Papers 51, Queen Mary, University of London, School of Business and Management, Centre for Globalisation Research.

Neal, D. (1995). Industry-specific human capital: Evidence from displaced workers. Journal of Labor Economics, 13(4):653-677.

Parent, D. (2000). Industry-specific capital and the wage profile: Evidence from the National Longitudinal Survey of Youth and the Panel Study of Income Dynamics. Journal of Labor Economics, 18(2):306-323.

Poletaev, M. and Swaim, P. (2008). Human capital specificity: evidence from the dictionary of occupational titles and displaced worker surveys, 1984-2000. Journal of Labor Economics, 26(3):387-420.

Topel, R. H. (1991). Specific capital, mobility, and wages: Wages rise with job seniority. Journal of Political Economy, 99(1):145-76.

Topel, R. H. and Ward, M. P. (1992). Job mobility and the careers of young men. The Quarterly Journal of Economics, 107(2):439-479.

Torres, S., Portugal, P., Addison, J., and Guimarães, P. (2013). The sources of wage variation: a three-way high-dimensional fixed effects model. Working Papers w20139, Banco de Portugal, Economics and Research Department.

Webber, D. A. (2013). Firm Market Power and the Earnings Distribution. IZA Discussion Papers 7342, Institute for the Study of Labor (IZA).

Woodcock, S. D. (2007). Match effects. Technical Report 07-13, SFU Discussion Paper.

Woodcock, S. D. (2008). Wage differentials in the presence of unobserved worker, firm, and match heterogeneity. Labour Economics, 15(4):771-793. 


\section{Appendix}

\section{Appendix A}

Table 8: Descriptive statistics

\begin{tabular}{lrr} 
& Non-displaced & Displaced \\
\hline Total monthly wage (2013 euros) & 1258 & 1067 \\
Minimum monthly wage (2013 euros) & 485 & 485 \\
Age (in years) & 38 & 37 \\
Tenure (in years) & 10 & 6 \\
Female (\%) & 40 & 47 \\
& & \\
Education (\%): & 3 & 2 \\
Less than basic school & 29 & 32 \\
Basic school & 18 & 25 \\
Preparatory & 18 & 17 \\
Lower Secondary & 19 & 16 \\
Upper Secondary & 13 & 8 \\
College & & \\
& 1131 & 511 \\
Firm size (no. co-workers) & & \\
& & \\
Industry (\%): & 40 & 58 \\
Manufacturing & 8 & 17 \\
Construction & 19 & 4 \\
Wholesale and retail trade & 8 & 5 \\
Transports & 14 & \\
Financial services & 11 & \\
Education/health & & \\
& $21,357,678$ & \\
No. observations & & \\
\hline Notes: This table reports summary statistics (mean) for the sample. The units are explained in \\
parentheses.
\end{tabular}




\section{Appendix B}

Table 9: Detailed results from Figures 2 and 3 - FE model without trends

\begin{tabular}{|c|c|c|c|c|c|c|c|c|c|c|c|c|}
\hline \multicolumn{7}{|c|}{ Monthly earnings loss } & \multicolumn{6}{|c|}{$\begin{array}{c}\text { Monthly wage loss } \\
\text { Robust }\end{array}$} \\
\hline & Coef. & Std. Err. & $\mathrm{t}$ & $\mathrm{P}>\mathrm{t}$ & {$[95 \%$ Conf. } & Interval] & Coef. & Std. Err. & $\mathrm{t}$ & $\mathrm{P}>\mathrm{t}$ & {$[95 \%$ Conf. } & Interval] \\
\hline$D_{-10}$ & -0.031 & 0.004 & -7.030 & 0.000 & -0.039 & -0.022 & 0.105 & 0.002 & 47.920 & 0.000 & 0.100 & 0.109 \\
\hline$D_{-9}$ & 0.009 & 0.004 & 2.160 & 0.031 & 0.001 & 0.017 & 0.102 & 0.002 & 50.790 & 0.000 & 0.098 & 0.106 \\
\hline$D_{-8}$ & 0.017 & 0.004 & 4.300 & 0.000 & 0.009 & 0.025 & 0.099 & 0.002 & 51.170 & 0.000 & 0.095 & 0.103 \\
\hline$D_{-7}$ & 0.011 & 0.004 & 3.010 & 0.003 & 0.004 & 0.018 & 0.093 & 0.002 & 52.380 & 0.000 & 0.090 & 0.097 \\
\hline$D_{-6}$ & 0.044 & 0.004 & 12.420 & 0.000 & 0.037 & 0.051 & 0.119 & 0.002 & 65.050 & 0.000 & 0.115 & 0.122 \\
\hline$D_{-5}$ & 0.016 & 0.003 & 4.870 & 0.000 & 0.010 & 0.023 & 0.085 & 0.002 & 52.290 & 0.000 & 0.082 & 0.088 \\
\hline$D_{-4}$ & -0.015 & 0.003 & -4.710 & 0.000 & -0.021 & -0.009 & 0.073 & 0.002 & 46.190 & 0.000 & 0.070 & 0.076 \\
\hline$D_{-3}$ & -0.016 & 0.003 & -5.250 & 0.000 & -0.022 & -0.010 & 0.073 & 0.002 & 46.400 & 0.000 & 0.070 & 0.076 \\
\hline$D_{-2}$ & -0.032 & 0.003 & -10.810 & 0.000 & -0.038 & -0.026 & 0.071 & 0.002 & 46.260 & 0.000 & 0.068 & 0.074 \\
\hline$D_{-1}$ & -0.042 & 0.003 & -14.250 & 0.000 & -0.048 & -0.036 & 0.064 & 0.002 & 41.630 & 0.000 & 0.061 & 0.067 \\
\hline$D_{0}$ & -0.034 & 0.003 & -12.530 & 0.000 & -0.039 & -0.029 & 0.056 & 0.002 & 37.140 & 0.000 & 0.053 & 0.059 \\
\hline$D_{1}$ & -2.424 & 0.008 & -286.350 & 0.000 & -2.440 & -2.407 & 0.037 & 0.002 & 19.240 & 0.000 & 0.033 & 0.040 \\
\hline$D_{2}$ & -2.018 & 0.008 & -254.590 & 0.000 & -2.034 & -2.003 & 0.022 & 0.002 & 12.100 & 0.000 & 0.018 & 0.025 \\
\hline$D_{3}$ & -1.710 & 0.008 & -217.310 & 0.000 & -1.725 & -1.695 & 0.005 & 0.002 & 2.870 & 0.004 & 0.002 & 0.008 \\
\hline$D_{4}$ & -1.486 & 0.008 & -188.430 & 0.000 & -1.502 & -1.471 & -0.009 & 0.002 & -5.300 & 0.000 & -0.012 & -0.006 \\
\hline$D_{5}$ & -1.390 & 0.008 & -170.580 & 0.000 & -1.405 & -1.374 & -0.019 & 0.002 & -11.060 & 0.000 & -0.022 & -0.015 \\
\hline$D_{6}$ & -1.298 & 0.009 & -152.340 & 0.000 & -1.315 & -1.281 & -0.024 & 0.002 & -14.100 & 0.000 & -0.028 & -0.021 \\
\hline$D_{7}$ & -1.210 & 0.009 & -137.840 & 0.000 & -1.228 & -1.193 & -0.033 & 0.002 & -19.470 & 0.000 & -0.036 & -0.029 \\
\hline$D_{8}$ & -1.107 & 0.009 & -119.360 & 0.000 & -1.125 & -1.089 & -0.042 & 0.002 & -24.320 & 0.000 & -0.045 & -0.038 \\
\hline$D_{9}$ & -0.992 & 0.010 & -103.910 & 0.000 & -1.011 & -0.974 & -0.039 & 0.002 & -23.010 & 0.000 & -0.042 & -0.036 \\
\hline$D_{10}$ & -0.756 & 0.009 & -84.200 & 0.000 & -0.774 & -0.738 & -0.042 & 0.002 & -27.040 & 0.000 & -0.045 & -0.039 \\
\hline
\end{tabular}

Notes: Log monthly earnings (wage) loss of displaced workers due to firm closure, including (excluding) transitions

to zeros. In the regressions we control for age, age squared, and calendar year fixed effects. 
Table 10: Detailed results from Figure 2: fixed-effects model and random trends model (without and with trends)

\begin{tabular}{|c|c|c|c|c|c|c|c|c|c|c|c|c|}
\hline \multicolumn{7}{|c|}{$\begin{array}{l}\text { FE model } \\
\text { Without trends }\end{array}$} & \multicolumn{6}{|c|}{$\begin{array}{l}\text { Random trends model } \\
\text { With trends }\end{array}$} \\
\hline & Coef. & Std. Err. & $\mathrm{t}$ & $\mathrm{P}>\mathrm{t}$ & [95\% Conf. & Interval] & Coef. & Std. Err. & $\mathrm{t}$ & $\mathrm{P}>\mathrm{t}$ & [95\% Conf. & Interval] \\
\hline$D_{-10}$ & -0.031 & 0.004 & -7.030 & 0.000 & -0.039 & -0.022 & -0.001 & 0.001 & -0.800 & 0.425 & -0.004 & 0.002 \\
\hline$D_{-9}$ & 0.009 & 0.004 & 2.160 & 0.031 & 0.001 & 0.017 & -0.003 & 0.001 & -2.350 & 0.019 & -0.005 & 0.000 \\
\hline$D_{-8}$ & 0.017 & 0.004 & 4.300 & 0.000 & 0.009 & 0.025 & 0.003 & 0.001 & 2.290 & 0.022 & 0.000 & 0.005 \\
\hline$D_{-7}$ & 0.011 & 0.004 & 3.010 & 0.003 & 0.004 & 0.018 & -0.005 & 0.001 & -5.070 & 0.000 & -0.007 & -0.003 \\
\hline$D_{-6}$ & 0.044 & 0.004 & 12.420 & 0.000 & 0.037 & 0.051 & 0.026 & 0.001 & 26.730 & 0.000 & 0.024 & 0.027 \\
\hline$D_{-5}$ & 0.016 & 0.003 & 4.870 & 0.000 & 0.010 & 0.023 & -0.001 & 0.001 & -1.610 & 0.108 & -0.003 & 0.000 \\
\hline$D_{-4}$ & -0.015 & 0.003 & -4.710 & 0.000 & -0.021 & -0.009 & -0.003 & 0.001 & -5.210 & 0.000 & -0.004 & -0.002 \\
\hline$D_{-3}$ & -0.016 & 0.003 & -5.250 & 0.000 & -0.022 & -0.010 & 0.000 & 0.001 & -0.430 & 0.664 & -0.001 & 0.001 \\
\hline$D_{-2}$ & -0.032 & 0.003 & -10.810 & 0.000 & -0.038 & -0.026 & 0.005 & 0.000 & 9.530 & 0.000 & 0.004 & 0.006 \\
\hline$D_{-1}$ & -0.042 & 0.003 & -14.250 & 0.000 & -0.048 & -0.036 & 0.002 & 0.001 & 3.820 & 0.000 & 0.001 & 0.003 \\
\hline$D_{0}$ & -0.034 & 0.003 & -12.530 & 0.000 & -0.039 & -0.029 & -0.003 & 0.000 & -6.010 & 0.000 & -0.004 & -0.002 \\
\hline$D_{1}$ & -2.424 & 0.008 & -286.350 & 0.000 & -2.440 & -2.407 & -2.361 & 0.008 & -283.390 & 0.000 & -2.377 & -2.345 \\
\hline$D_{2}$ & -2.018 & 0.008 & -254.590 & 0.000 & -2.034 & -2.003 & -2.006 & 0.008 & -260.290 & 0.000 & -2.021 & -1.991 \\
\hline$D_{3}$ & -1.710 & 0.008 & -217.310 & 0.000 & -1.725 & -1.695 & -1.720 & 0.008 & -224.360 & 0.000 & -1.735 & -1.705 \\
\hline$D_{4}$ & -1.486 & 0.008 & -188.430 & 0.000 & -1.502 & -1.471 & -1.513 & 0.008 & -195.510 & 0.000 & -1.528 & -1.498 \\
\hline$D_{5}$ & -1.390 & 0.008 & -170.580 & 0.000 & -1.405 & -1.374 & -1.447 & 0.008 & -177.670 & 0.000 & -1.463 & -1.431 \\
\hline$D_{6}$ & -1.298 & 0.009 & -152.340 & 0.000 & -1.315 & -1.281 & -1.389 & 0.009 & -161.440 & 0.000 & -1.406 & -1.372 \\
\hline$D_{7}$ & -1.210 & 0.009 & -137.840 & 0.000 & -1.228 & -1.193 & -1.319 & 0.009 & -148.290 & 0.000 & -1.336 & -1.301 \\
\hline$D_{8}$ & -1.107 & 0.009 & -119.360 & 0.000 & -1.125 & -1.089 & -1.228 & 0.009 & -129.920 & 0.000 & -1.246 & -1.209 \\
\hline$D_{9}$ & -0.992 & 0.010 & -103.910 & 0.000 & -1.011 & -0.974 & -1.116 & 0.010 & -116.410 & 0.000 & -1.135 & -1.097 \\
\hline$D_{10}$ & -0.756 & 0.009 & -84.200 & 0.000 & -0.774 & -0.738 & -0.862 & 0.009 & -95.740 & 0.000 & -0.879 & -0.844 \\
\hline
\end{tabular}

Notes: Log monthly earnings loss of displaced workers due to firm closure, including transitions to zeros. In the regressions we control for age, age squared, and calendar year fixed effects. 


\section{Appendix C - The three-way high-dimensional fixed effects regression model}

In this Appendix we describe the procedure that allows estimation of a wage equation that incorporates three high-dimensional fixed effects in order to be able to identify worker, firm, and job title fixed effects. For this exercise we need to use a modified version of the methodology initially developed by Abowd et al. (1999) and Abowd et al. (2002) and extended by Guimarães and Portugal (2010) to work with large datasets and for three fixed effects.

The baseline specification is Equation (2).

where $\alpha_{i}$ is a worker fixed effect, $\lambda_{j}$ is a job title fixed effect, and $\theta_{f}$ is a firm fixed effect. $w_{i j f t}$ represents the monthly wage for each individual $i$ in job $j$ working for firm $f$ in year $t$. $D_{i t}^{k}$ are dummy variables where $k$ is equal to $-m,-(m-1), \ldots, 0,1,2, \ldots$, which represent jointly the event of displacement. $\delta_{k}$ represents the effect of displacement on worker's earnings $k$ years prior to, and following, its occurrence. $X_{i t}$ controls for age and age squared for each individual $i$ in year $t, \gamma_{t}$ are calendar year fixed effects, $\epsilon_{i j f t}$ is assumed to follow the conventional assumptions.

In matrix format, the stacked system has the following form:

$$
\mathbf{W}=\alpha \mathbf{F}_{\mathbf{1}}+\lambda \mathbf{F}_{\mathbf{2}}+\theta \mathbf{F}_{\mathbf{3}}+\phi \mathbf{Z}+\epsilon
$$

In this equation $F_{1}, F_{2}$, and $F_{3}$ are high-dimensional matrices for the worker, job, and firm fixed effects, respectively. $Z$ is a matrix of the explanatory variables and calendar year fixed effects from equation (2).

The least squares estimators of $\phi, \alpha, \lambda$, and $\theta$ solve the following equations:

$$
\left[\begin{array}{cccc}
Z^{\prime} Z & Z^{\prime} F_{1} & Z^{\prime} F_{2} & Z^{\prime} F_{3} \\
F_{1}^{\prime} Z & F_{1}^{\prime} F_{1} & F_{1}^{\prime} F_{2} & F_{1}^{\prime} F_{3} \\
F_{2}^{\prime} Z & F_{2}^{\prime} F_{1} & F_{2}^{\prime} F_{2} & F_{2}^{\prime} F_{3} \\
F_{3}^{\prime} Z & F_{3}^{\prime} F_{1} & F_{3}^{\prime} F_{2} & F_{3}^{\prime} F_{3}
\end{array}\right]\left[\begin{array}{c}
\phi \\
\alpha \\
\lambda \\
\theta
\end{array}\right]=\left[\begin{array}{c}
Z^{\prime} W \\
F_{1}^{\prime} W \\
F_{2}^{\prime} W \\
F_{3}^{\prime} W
\end{array}\right]
$$

It is computationally difficult to invert the left matrix due to the large number of workers, firms, and job titles. Herein we use an iterative solution that alternates between estimation of $\phi, \alpha, \theta$, and $\lambda$.

$$
\left[\begin{array}{c}
\phi \\
\alpha \\
\lambda \\
\theta
\end{array}\right]=\left[\begin{array}{c}
\left(Z^{\prime} Z\right)^{-1} Z^{\prime}\left(W-\alpha F_{1}-\theta F_{2}-\lambda F_{3}\right) \\
\left(F_{1}^{\prime} F_{1}\right)^{-1} F_{1}^{\prime}\left(W-\theta F_{2}-\lambda F_{3}-\phi Z\right) \\
\left(F_{2}^{\prime} F_{2}\right)^{-1} F_{2}^{\prime}\left(W-\alpha F_{1}-\theta F_{3}-\phi Z\right) \\
\left(F_{3}^{\prime} F_{3}\right)^{-1} F_{3}^{\prime}\left(W-\alpha F_{1}-\lambda F_{2}-\phi Z\right)
\end{array}\right]
$$

It is clear from the previous equations that at each iteration the fixed effects are simply computed as averages of the residuals. For an example, $\left(F_{3}^{\prime} F_{3}\right)^{-1} F_{3}^{\prime}$ is simply a demeaning operator for the firm fixed effect. The iterative solution alternates between estimation of $\phi, \alpha, \lambda$, and $\theta$ and proceeds as follows. 
First, the algorithm makes use of the Frish-Waugh-Lovell theorem to remove the influence of the three high-dimensional fixed effects from each individual variable. Through the recursive algorithm the current value of $\phi$ can be used to estimate the current value of $\alpha$. In estimating $\lambda$ the previous values of $\phi$ and $\alpha$ are used. In estimating $\theta$ the previous values of $\lambda, \phi$, and $\alpha$ are used. Then the algorithm restarts and will converge because the parameter updates are chosen according to the equations in (7). Next, we estimate the regression using the transformed variables with a correction to the degrees of freedom. This approach yields the exact least squares solution for the coefficients and standard errors.

The fixed effects in equation (2) were estimated using the complete data set, which covers the employed population in the private sector in Portugal with all available information from 1986 to 2013 and has a total of 22,412,051 observations. The identification of the three high dimensional fixed effects given by the worker, firm, and job title effects was circumvented by applying the algorithm of Abowd et al. (2002), based on graph theory to determine groups of connected individuals, firms, and job titles. A connected group exists when at least one element of a worker, job title, and firm links the rest of the group. The largest connected group represents more than 99 percent of the sample. 


\section{Appendix D - Decomposition of the wage loss - dis- placed workers due to collective dismissals}

\begin{tabular}{|c|c|c|c|c|c|c|}
\hline $\begin{array}{r}\text { Period } \\
\text { relative } \\
\text { to displacement }\end{array}$ & Base & Full & $\delta_{k}^{\text {base }}-\delta_{k}^{\text {full }}$ & $\begin{array}{c}\text { Firm } \\
\text { fixed effect }\end{array}$ & $\begin{array}{c}\text { Match } \\
\text { fixed effect }\end{array}$ & $\begin{array}{l}\text { Job title } \\
\text { fixed effect }\end{array}$ \\
\hline$D_{-10}$ & 0.10 & -0.01 & 0.11 & 0.05 & 0.03 & 0.03 \\
\hline$D_{-9}$ & 0.09 & -0.02 & 0.11 & 0.05 & 0.03 & 0.03 \\
\hline$D_{-8}$ & 0.09 & -0.02 & 0.11 & 0.05 & 0.03 & 0.03 \\
\hline$D_{-7}$ & 0.09 & -0.02 & 0.11 & 0.05 & 0.03 & 0.03 \\
\hline$D_{-6}$ & 0.11 & -0.01 & 0.11 & 0.06 & 0.03 & 0.03 \\
\hline$D_{-5}$ & 0.09 & -0.03 & 0.11 & 0.06 & 0.03 & 0.03 \\
\hline$D_{-4}$ & 0.08 & -0.03 & 0.11 & 0.05 & 0.03 & 0.02 \\
\hline$D_{-3}$ & 0.07 & -0.03 & 0.10 & 0.05 & 0.03 & 0.02 \\
\hline$D_{-2}$ & 0.07 & -0.03 & 0.10 & 0.05 & 0.03 & 0.02 \\
\hline$D_{-1}$ & 0.07 & -0.03 & 0.10 & 0.05 & 0.03 & 0.02 \\
\hline$D_{0}$ & 0.07 & -0.03 & 0.10 & 0.05 & 0.03 & 0.02 \\
\hline$D_{1}$ & 0.04 & -0.02 & 0.06 & 0.04 & 0.01 & 0.02 \\
\hline$D_{2}$ & 0.03 & -0.01 & 0.04 & 0.03 & 0.00 & 0.01 \\
\hline$D_{3}$ & 0.02 & -0.01 & 0.03 & 0.02 & 0.00 & 0.01 \\
\hline$D_{4}$ & 0.01 & -0.01 & 0.02 & 0.01 & 0.00 & 0.01 \\
\hline$D_{5}$ & 0.00 & -0.01 & 0.01 & 0.01 & -0.01 & 0.01 \\
\hline$D_{6}$ & 0.00 & 0.00 & 0.00 & 0.00 & -0.01 & 0.01 \\
\hline$D_{7}$ & -0.01 & 0.00 & -0.01 & 0.00 & -0.01 & 0.00 \\
\hline$D_{8}$ & -0.01 & 0.00 & -0.01 & 0.00 & -0.01 & 0.00 \\
\hline$D_{9}$ & -0.01 & 0.00 & -0.01 & 0.00 & -0.01 & 0.00 \\
\hline$D_{10}$ & -0.01 & 0.00 & -0.01 & -0.01 & -0.01 & 0.00 \\
\hline$\mu_{\text {Pre-displacement }}$ & 0.08 & -0.02 & 0.11 & 0.05 & 0.03 & 0.03 \\
\hline$\mu_{\text {Post-displacement }}$ & 0.01 & 0.00 & 0.01 & 0.01 & 0.00 & 0.01 \\
\hline$\Delta$ & -0.08 & 0.02 & -0.10 & -0.04 & -0.03 & -0.02 \\
\hline
\end{tabular}

Notes: This table reports the Gelbach decomposition of the two fixed effects of the wage loss of displaced workers. In the regressions we control for age, age squared, and calendar year fixed effects. All regressions are computed with worker fixed effects. In each column $\mu_{\text {Pre-displacement }}$ is the computed average between the first eleven lines $\left(D_{-10}\right.$ to $\left.D_{0}\right)$. $\mu_{\text {Post-displacement }}$ is the computed average between the next ten lines $\left(D_{1}\right.$ to $\left.D_{10}\right)$. In the line $\Delta$ we compute the difference between the previous two lines. 